\title{
34. PORE-WATER CHEMISTRY AND CARBONATE DIAGENESIS IN SEDIMENTS FROM LEG 115: INDIAN OCEAN ${ }^{1}$
}

\author{
Peter K. Swart ${ }^{2}$ and Stephen J. Burns ${ }^{2,3}$
}

\begin{abstract}
Analyses of the $\mathrm{Sr}^{2+}$ concentrations of interstitial fluids obtained from sediments squeezed during Leg 115 were used to estimate the rates and total amount of recrystallization of biogenic carbonates. The total amount of recrystallization calculated using this method varies from less than 1\% in sediments at Site 706 to more than $40 \%$ at Site 709 in sediments of $47 \mathrm{Ma}$. Five of the sites drilled during Leg 115 (Sites 707 through 711) were drilled in a depth transect within a restricted geographic area so that theoretically they received similar amounts of sediment input. Of these, the maximum rate of recrystallization occurred in the upper $50 \mathrm{~m}$ of Site $710(3812 \mathrm{~m})$. The amount of recrystallization decreased with increasing water depth at Sites $708(4096 \mathrm{~m})$ and $711(4428 \mathrm{~m})$, presumably as a result of the fact that most of the reactive calcium carbonate was dissolved before burial. We also observed significant alkalinity deficits at many of these sites, a condition which most likely resulted from the precipitation of calcium carbonate either in the sedimentary column, or during retrieval of the core. Precipitation of $\mathrm{CaCO}_{3}$ as a result of pressure changes during core retrieval was confirmed by the comparison of $\mathrm{Ca}^{2+}$ and alkalinity from water samples obtained using the in-situ sampler and squeezed from the sediments. At Sites 707 and 716, the shallowest sites, no calcium or alkalinity deficits were present. In spite of our estimations of as much as $45 \%$ recrystallization at Site 709 , all the carbonate sites exhibited what would be previously considered conservative $\mathrm{Ca}^{2+} / \mathrm{Mg}^{2+}$ profiles, which varied from -1 to -0.5 . By virtue of the position of these sites relative to known basaltic basement or through the actual penetration of basalt (i.e., Sites 706, 707 and 712 ), these sites are all known to be underlain by basalt. Our results suggest, therefore, that more positive $\mathrm{Ca}^{2+} / \mathrm{Mg}^{2+}$ gradients cannot necessarily be used as indicators of the nature of basement material.
\end{abstract}

\section{INTRODUCTION}

In previous studies, pore-water analyses of fluids squeezed from carbonate sediments have provided abundant information on diagenetic reactions which take place during burial of deep sea sediments (see Gieskes, 1981). Such methods are potentially much more powerful in studying diagenesis than examining sediments using the scanning electron microscope (SEM), X-ray diffraction (XRD), or even by chemical means, as small amounts of reaction between the sediments and pore waters produce large changes in the accompanying interstitial fluids.

As a first approximation, deep-sea carbonates can be separated into two categories based upon the dominant mineralogies of the original sediments. The majority consist of relatively stable low-Mg calcite coccoliths and foraminifers. Diagenetic processes in these sediments have been studied by numerous workers (Schlanger and Douglas, 1974; Lawrence et al., 1975; Matter et al., 1975; Sayles and Manheim, 1975; Gieskes, 1981; Baker et al., 1982; Elderfield et al., 1982; Stout, 1985a,b and others).

The second type of sediment generally found near shallowwater carbonate platforms consists of a mixture of metastable minerals, high-Mg calcite (HMC), and aragonite as well as low$\mathrm{Mg}$ calcite (LMC). This type of sediment has been termed periplatform sediment (Schlager and James, 1978). The metastable minerals originate on carbonate platforms and become admixed with normal pelagic components during deposition. In contrast to the pure pelagic LMC deposits, pore waters from this type of assemblage have been studied in only one previous study (Swart and Guzikowski, 1988). That investigation involved material re-

${ }^{1}$ Duncan, R. A., Backman, J., Peterson, L. C., et al., 1990. Proc. ODP, Sci. Results, 115: College Station, TX (Ocean Drilling Program).

2 Stable Isotope Laboratory, Marine Geology and Geophysics, Rosenstiel School of Marine and Atmospheric Science, University of Miami, Miami, FL 33149, U.S.A. land.

${ }_{3}$ Present address: Geologisches Institut, Balterstrasse 1, CH-3012 Bern, Switzer- covered during Leg 101 off Little Bahama Bank and in Exuma Sound, in the Bahamas.

This investigation will examine diagenetic reactions using $\mathrm{Ca}^{2+}, \mathrm{Mg}^{2+}$, and $\mathrm{Sr}^{2+}$ gradients in both these types of deposits. In particular, the close spacing of the Leg 115 "carbonate" transect sites (Sites 707 through 711) in a range of water depths allows an examination of the influence of initial water depth on the recrystallization of calcite.

\section{ANALYTICAL METHODS}

Pore waters were squeezed from 10-cm-long, whole-round samples on board ship immediately after coring. The water depths and depths of penetration are shown in Table 1. Site locations are shown in Figure 1. Methods and equipment for porewater extraction have been described previously by Manheim and Sayles (1974). At Site 709, samples were also retrieved using the Barnes in-situ water sampler.

The pore waters were then titrated for $\mathrm{Cl}^{-}, \mathrm{Ca}^{2+}$, and $\mathrm{Mg}^{2+}$ by methods similar to those described by Gieskes $(1973,1974)$. Dissolved $\mathrm{SO}_{4}^{2-}$ was determined using an ion chromatograph. Alkalinity was determined using a potentiometric titration method as developed by Dyrssen and Sillen (1967) and others (See Grasshof, 1976). Samples were titrated with $0.1 \mathrm{HCl}$ made up in a $0.7 \mathrm{M} \mathrm{NaCl}$ solution. The initial $\mathrm{pH}$ was measured using electrodes calibrated with TRIS-TRISHCl buffers made up using a $0.7 \mathrm{M} \mathrm{NaCl}$ solution and reported relative to the free hydrogen scale (Hansson, 1973).

Pore-water $\mathrm{Sr}^{2+}$ concentrations were determined by atomic absorption spectrophotometry. These values have been used to correct the initial $\mathrm{Ca}^{2+}$ and $\mathrm{Mg}^{2+}$ concentrations reported in Backman, Duncan et al. (1988) according to the procedure of Gieskes and Peretsman (1986). For this reason values reported in this paper are slightly lower than in the original report. For the solid samples, coarse and fine fraction were separated using wet sieving through a $63 \mu \mathrm{m}$ sieve using buffered sodium borate solution $(\mathrm{pH}=8)$. Samples were then dried at $40^{\circ} \mathrm{C}$, dissolved us- 
Table 1. Water depth and depth of penetration of sites investigated during Leg 115.

\begin{tabular}{ccc}
\hline & $\begin{array}{c}\text { Water } \\
\text { depth } \\
\text { Hole }\end{array}$ & $\begin{array}{c}\text { Penetration } \\
\text { (mbsf) }\end{array}$ \\
\hline $705 \mathrm{~A}$ & 2318 & 27.5 \\
$706 \mathrm{~A}$ & 2504.3 & 47.5 \\
$706 \mathrm{~B}$ & 2507.8 & 36.7 \\
$706 \mathrm{C}$ & 2519.0 & 44.3 \\
$707 \mathrm{~A}$ & 1552.3 & 212.3 \\
$707 \mathrm{~B}$ & 1552.3 & 124.1 \\
$707 \mathrm{C}$ & 1552.3 & 438.7 \\
$708 \mathrm{~A}$ & 4096.5 & 234.7 \\
$709 \mathrm{~A}$ & 3038.2 & 203.1 \\
$709 \mathrm{~B}$ & 3038.2 & 254.8 \\
$709 \mathrm{C}$ & 3038.2 & 353.7 \\
$710 \mathrm{~A}$ & 3812.0 & 209.7 \\
$710 \mathrm{~B}$ & 3810.5 & 83.4 \\
$711 \mathrm{~A}$ & 4428.2 & 249.6 \\
$711 \mathrm{~B}$ & 4429.7 & 98.3 \\
$712 \mathrm{~A}$ & 2904.3 & 115.3 \\
$713 \mathrm{~A}$ & 2915.3 & 155.1 \\
$714 \mathrm{~A}$ & 2038.3 & 233.0 \\
$714 \mathrm{~B}$ & 2038.3 & 122.6 \\
$715 \mathrm{~A}$ & 2266.3 & 211.3 \\
$716 \mathrm{~A}$ & 544.3 & 257.1 \\
\hline
\end{tabular}

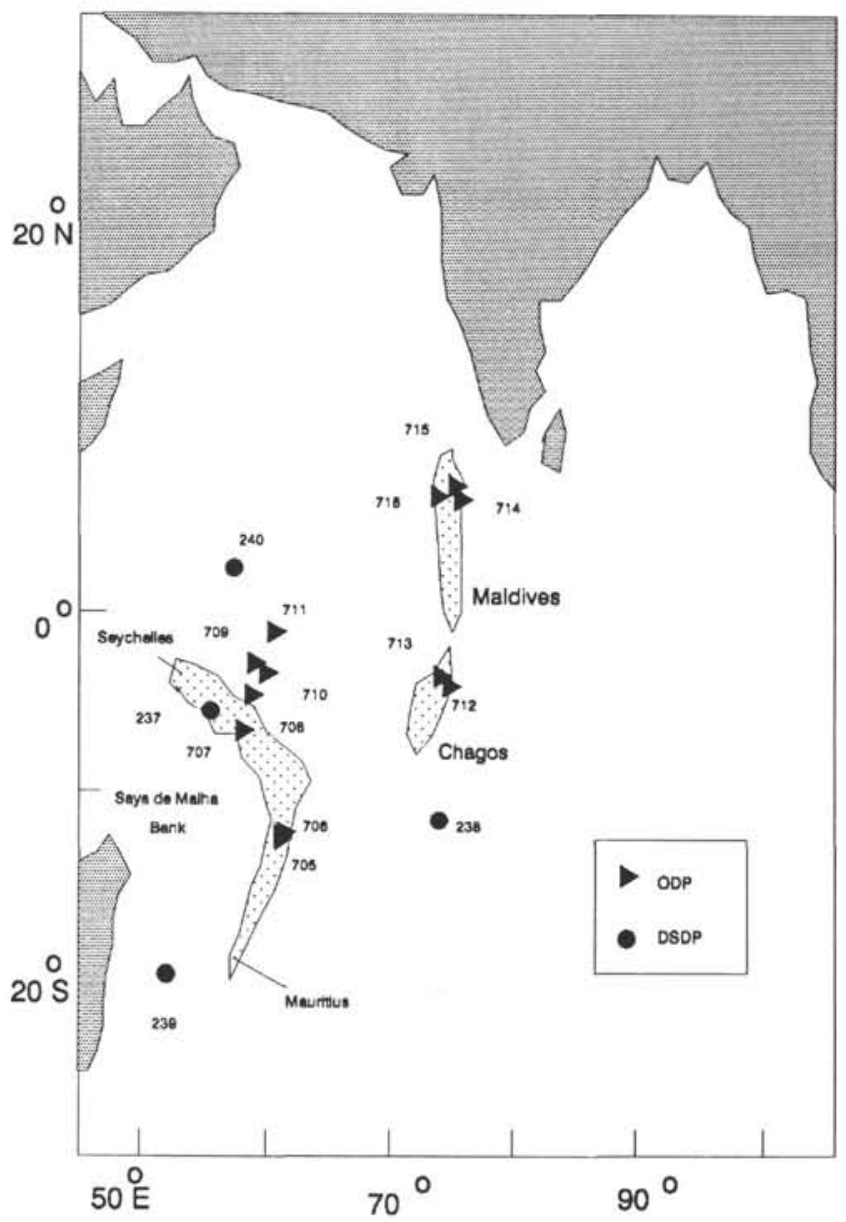

Figure 1. Location map for ODP sites drilled during Leg 115. ing $10 \% \mathrm{HNO}_{3}$ and diluted to the required concentration using $1500 \mu \mathrm{M} \mathrm{La}, 1 \% \mathrm{HNO}_{3}$ solution. Strontium concentrations were determined with an atomic absorption spectrophotometer.

\section{RESULTS}

\section{Pore Waters}

With the exception of the $\mathrm{Sr}^{2+}$ data, all other pore-water parameters have been reported in Backman, Duncan, et al. (1988). As noted in the "Analytical Methods" in this chapter, the concentration of $\mathrm{Ca}^{2+}$ and $\mathrm{Mg}^{2+}$ have been adjusted for the concentration of $\mathrm{Sr}^{2+}$ and are therefore different from those originally reported.

\section{Calcium and Magnesium}

The concentration of $\mathrm{Ca}^{2+}$ in interstitial waters generally increased downcore, whereas $\mathrm{Mg}^{2+}$ decreased. The magnitude of these changes varied between 0.006 and $.059 \mathrm{mM} / \mathrm{m}$ for $\mathrm{Ca}^{2+}$, and between 0.009 and $0.089 \mathrm{mM} / \mathrm{m}$ for $\mathrm{Mg}^{2+}$ (see Table 1). Samples from Site 709 (WS-12, WS-15 and WS-20), retrieved using the Barnes downhole water sampler, contained excess $\mathrm{Ca}^{2+}$ when compared to samples squeezed from comparable depths at the same site. Concentrations of $\mathrm{Mg}^{2+}$ from the in-situ sampler were not significantly different from those squeezed from the sediment (Table 1).

\section{Pore-water $\mathrm{Ca}^{2+} / \mathrm{Mg}^{2+}$ Gradients}

With the exception of Sites 705, 714, and 715, all sites show statistically significant negative relationships between $\mathrm{Ca}^{2+}$ and $\mathrm{Mg}^{2+}$ (Fig. 2). The slope of this relationship varies between -0.5 and -1.5 .

\section{Strontium}

Concentrations of $\mathrm{Sr}^{2+}$ increase downhole, by modest amounts compared to other previously studied Deep Sea Drilling Project (DSDP) and Ocean Drilling Project (ODP) sites (Gieskes, 1981) (Fig. 3). Site 716 exhibits the largest increase in $\mathrm{Sr}^{2+}$ to 512.3 $\mu \mathrm{M}$ at a depth of $195.75 \mathrm{mbsf}$. This site also exhibits saturation with respect to celestite by 137.8 mbsf (Fig. 4).

\section{Si Concentrations in Pore Waters}

Concentrations of $\mathrm{Si}$ in pore waters generally exhibit increase with depth downcore (Table 2). However, there are subtle differences between the various sites. In Site 707, concentrations of $\mathrm{Si}$ exhibit a gradual rise, reaching a concentration of $735 \mu \mathrm{M}$ at a depth of 79.95 mbsf. The concentrations exhibit a slight decrease between 10 and $20 \mathrm{Ma}$, although the precise extent of the decrease is blurred as a result of sample collection biases. Maximum Si concentrations of approximately $1000 \mu \mathrm{M}$ are obtained at 90 mbsf in sediments of $6.7 \mathrm{Ma}$.

A minimum concentration of $562 \mu \mathrm{M}$ is seen at $177.2 \mathrm{mbsf}$ in sediments of the late early Miocene. In older sediments, concentration levels of $\mathrm{Si}$ increase to concentrations similar to those observed in the top of the hole. Site 710 exhibits similar patterns of Si distribution to previous sites. The initially squeezed core exhibited a concentration of $631 \mu \mathrm{M}$, rising to $910 \mu \mathrm{M}$ at 53.85 mbsf. Below this depth, the concentration of $\mathrm{Si}$ decreases to $620 \mu \mathrm{M}$ at $112.7 \mathrm{mbsf}$ in sediments of the middle early Miocene. Concentrations of $\mathrm{Si}$ at the bottom of the hole are similar to other holes. Site 711 was the deepest drilled during Leg 115 , and exhibited the highest concentrations in the initially squeezed core (711 $\mu \mathrm{M}$ at $5.95 \mathrm{mbsf})$. Below this depth, concentrations decreased to $370 \mu \mathrm{M}$ at a depth of $53.75 \mathrm{mbsf}$ in sediments of $17.5 \mathrm{Ma}$.

In summary, all sites exhibit a rise in the concentration of $\mathrm{Si}$ in the interstitial pore waters downcore to between concentrations of 600 and $800 \mu \mathrm{M}$ in sediments of the Pliocene to late 


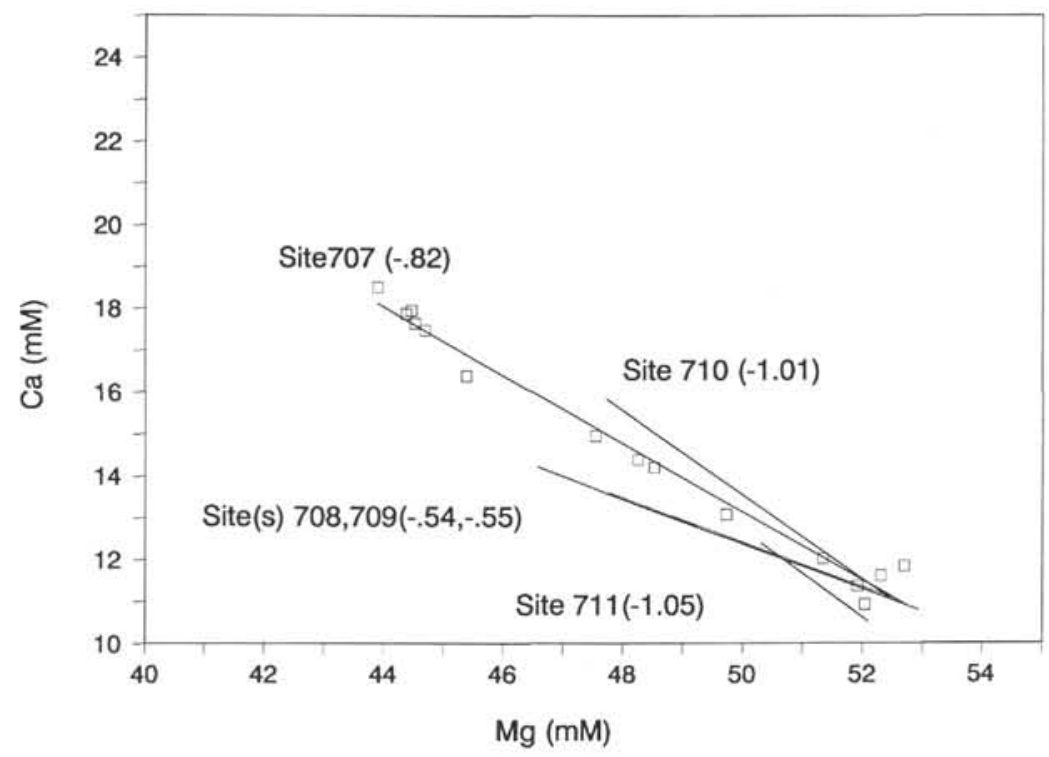

Figure 2. Calcium and magnesium gradients for Leg 115 sites; for clarity data points are only shown for Site 707. All other data are given in Table 2 .

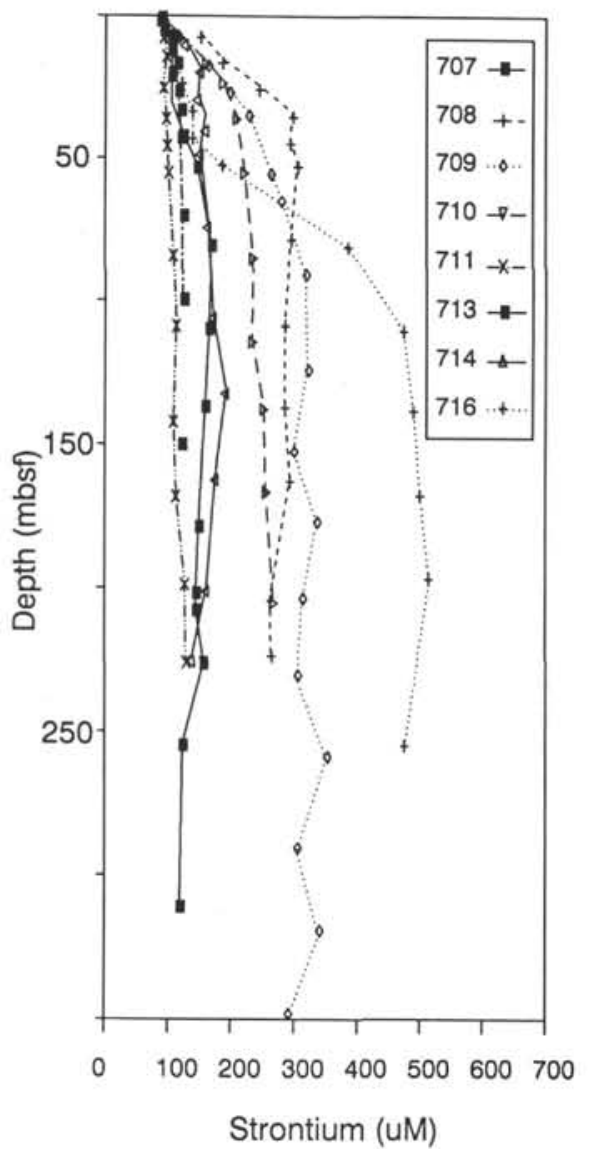

Figure 3. Concentrations of $\mathrm{Sr}^{2+}$ in interstitial pore fluids from Sites 707, $708,709,710,711$, and 716; data for other sites are given in Table 2.

Miocene. This is followed by a decrease in the middle Miocene and a subsequent rise in sediments of the late Eocene. The decrease in $\mathrm{Si}$ concentrations in the interstitial pore-water $\mathrm{Si}$ concentrations occurs in an interval depleted of siliceous microfossils

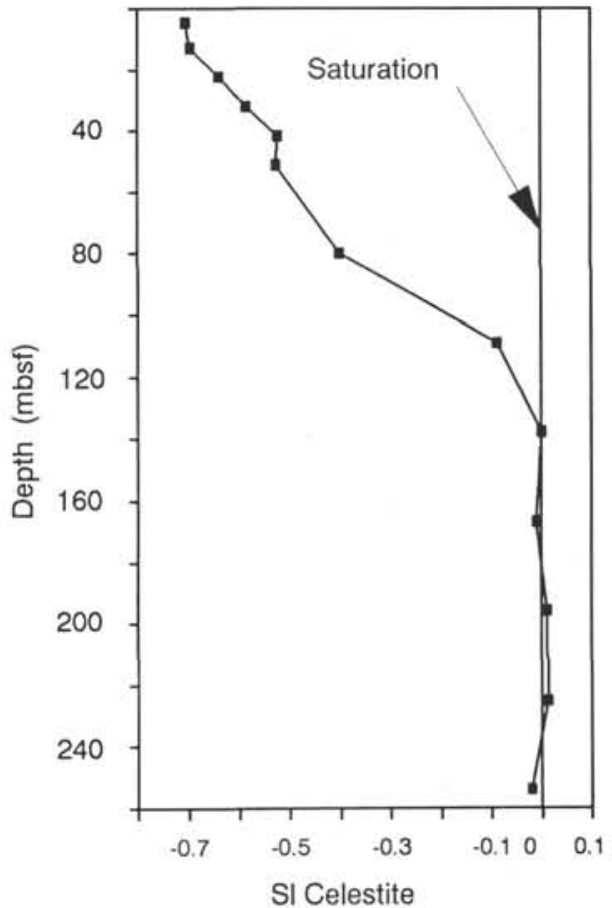

Figure 4. Saturation of pore fluids with respect to the mineral celestite at Site 716. Data for activity coefficient and solubility products are taken from Baker and Bloomer (1988). The SI is defined as SI $=\log$ (IAP/ $\mathrm{K}_{\mathrm{Sp}}$ celestite); $\mathrm{IAP}=$ ion activity product; $\mathrm{K}_{\mathrm{Sp}}$ celestite $=$ solubility product for celestite.

(Mikkelsen, this volume) (Fig. 5), but abundant in the diagenetic mineral clinoptilolite (Hempel and Bohrmann, this volume).

\section{Alkalinity, pH, Sulfate, Phosphate, and Ammonia}

Concentrations of organic material at all Leg 115 sites were extremely low, usually below detection limits $(0.02 \%$; Backman, Duncan, et al., 1988). In addition, no detectable concentrations of hydrocarbon gases were measured at any of the sites with the 
Table 2. Interstitial pore-water data for Sites 707 through 716. All data have been previously reported by Backman, Duncan, et al. (1988) with the exception of the $\mathrm{Sr}^{2+}$ concentrations and \% recrystallization. The $\mathrm{Ca}^{2+}$ and $\mathrm{Mg}^{2+}$ data have been corrected to account for changes in $\mathrm{Sr}^{2+}$.

\begin{tabular}{lrrrrrrrrrrrrrr}
\hline $\begin{array}{c}\text { Core, sample, } \\
\text { interval }(\mathrm{cm})\end{array}$ & $\begin{array}{c}\mathrm{Age} \\
(\mathrm{Ma})\end{array}$ & $\begin{array}{r}\text { Depth } \\
(\mathrm{mbsf})\end{array}$ & $\begin{array}{c}\mathrm{Ca}^{2+} \\
(\mathrm{mM})\end{array}$ & $\begin{array}{c}\mathrm{Mg}^{2+} \\
(\mathrm{mM})\end{array}$ & $\begin{array}{l}\mathrm{Sr}^{2+} \\
(\mu \mathrm{M})\end{array}$ & $\begin{array}{c}\mathrm{Cl}^{-} \\
(\mathrm{mM})\end{array}$ & $\begin{array}{c}\mathrm{Alk} \\
(\mathrm{mM})\end{array}$ & $\mathrm{pH}$ & $\mathrm{S}$ & $\begin{array}{c}\mathrm{Si} \\
(\mu \mathrm{M})\end{array}$ & $\begin{array}{c}\mathrm{NH}_{4}^{+} \\
(\mu \mathrm{M})\end{array}$ & $\begin{array}{c}\mathrm{SO}_{4}^{2-} \\
(\mathrm{mM})\end{array}$ & $\begin{array}{c}\mathrm{PO}_{4}^{3-} \\
(\mu \mathrm{M})\end{array}$ & $\begin{array}{c}\mathrm{Cumulative} \mathrm{\%}^{2} \\
\text { recrystallization }\end{array}$ \\
\hline Surface & 0.0 & 0.00 & 10.40 & 54.15 & - & 571.88 & 2.22 & 8.4 & 34.6 & 18 & 8.30 & 28.86 & - & $\mathrm{NC}$ \\
$1 \mathrm{H}-3,145-150$ & 0.9 & 4.45 & 11.27 & 52.02 & 86.1 & 564.95 & 3.01 & 7.9 & 35.0 & 272 & 38.00 & 27.71 & - & $\mathrm{NC}$ \\
$2 \mathrm{H}-, 145-150$ & 2.5 & 12.95 & 11.44 & 51.62 & 90.2 & 565.94 & 3.03 & 7.7 & 35.4 & 265 & 38.00 & 29.35 & - & $\mathrm{NC}$
\end{tabular}

Site 706

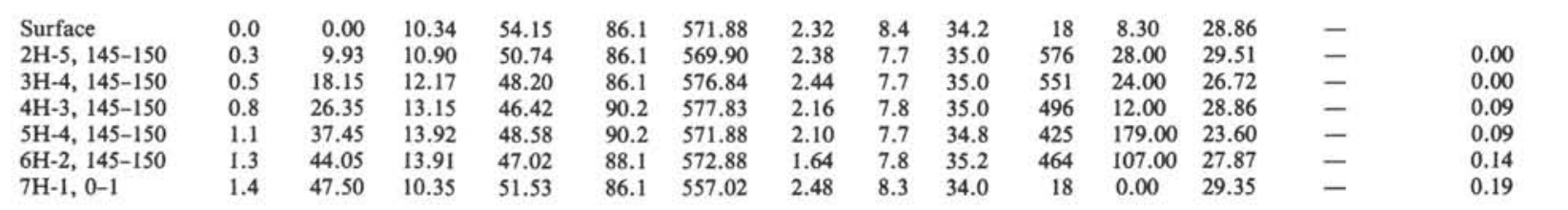

Site 707

$\begin{array}{lrrl}\text { Surface } & 0.0 & 0.00 & 10.18 \\ \text { 1H-3, 145-150 } & 0.9 & 4.45 & 10.94 \\ 2 \mathrm{H}-3,145-150 & 1.7 & 11.15 & 11.36 \\ 3 \mathrm{H}-2,145-150 & 1.7 & 19.15 & 11.61 \\ 4 \mathrm{H}-3,145-150 & 3.8 & 20.25 & 11.84 \\ 5 \mathrm{H}-4,145-150 & 4.4 & 41.45 & 12.00 \\ 6 \mathrm{H}-5,145-150 & 4.9 & 52.55 & 13.05 \\ 9 \mathrm{H}-4,145-150 & 6.6 & 79.95 & 14.15 \\ 12 \mathrm{H}-4,145-150 & 9.0 & 108.75 & 14.34 \\ 15 \mathrm{H}-3,145-150 & 18.8 & 136.05 & 14.91 \\ 20 \mathrm{X}-3,145-150 & 34.5 & 178.15 & 16.35 \\ 23 \mathrm{X}-3,145-150 & 36.0 & 200.95 & 17.92 \\ 3 \mathrm{R}-3,145-150 & 37.2 & 207.15 & 17.45 \\ 6 \mathrm{R}-2,145-150 & 38.5 & 225.45 & 17.83 \\ \text { 9R-2, 145-150 } & 40.0 & 254.35 & 18.49 \\ 15 \mathrm{R}-1,145-150 & 55.0 & 310.45 & 17.63\end{array}$

\begin{tabular}{|c|c|c|c|c|c|}
\hline 51.77 & 88.1 & 542.56 & 2.43 & 8.4 & 34.2 \\
\hline 52.04 & 92.2 & 554.16 & 2.90 & 7.6 & 35.5 \\
\hline 51.92 & 104.5 & 557.07 & 2.79 & 7.6 & 35.5 \\
\hline 52.31 & 104.5 & 563.84 & 2.86 & 7.6 & 35.6 \\
\hline 52.71 & 104.5 & 566.74 & 2.92 & 7.6 & 35.5 \\
\hline 51.35 & 122.9 & 560.93 & 2.90 & 7.4 & 35.0 \\
\hline 49.73 & 145.5 & 556.10 & 3.08 & 7.5 & 35.2 \\
\hline 48.53 & 168.0 & 553.20 & 3.21 & 7.6 & 35.2 \\
\hline 48.26 & 163.9 & 555.13 & 3.29 & 7.5 & 35.2 \\
\hline 47.54 & 157.8 & 556.10 & 3.27 & 7.6 & 35.2 \\
\hline 45.40 & 147.5 & 556.10 & 3.21 & 7.3 & 35.2 \\
\hline 44.47 & 143.4 & 556.10 & 3.41 & 7.4 & 34.8 \\
\hline 44.70 & 143.4 & 559.97 & 3.23 & 7.3 & 35.0 \\
\hline 44.38 & 155.7 & 554.16 & 3.18 & 7.5 & 34.8 \\
\hline 43.90 & 122.9 & 548.36 & 3.19 & 7.4 & 34.2 \\
\hline 44.53 & 118.8 & 550.30 & 2.62 & 7.6 & 34.0 \\
\hline
\end{tabular}

-
266
329
346
441
557
665
735
720
677
946
979
945
1011
1027
585

$\begin{array}{ll}0.00 & 28.06 \\ 0.00 & 28.92 \\ 0.00 & 29.91 \\ 0.00 & 29.75 \\ 0.00 & 29.75 \\ 0.00 & 29.58 \\ 0.00 & 28.56 \\ 0.00 & 28.56 \\ 0.00 & 30.93 \\ 0.00 & 28.90 \\ 0.00 & 28.49 \\ 0.00 & 28.07 \\ 0.00 & 28.66 \\ 0.00 & 28.75 \\ 0.00 & 28.90 \\ 0.00 & 28.92\end{array}$

$\begin{array}{lr}- & \\ - & 0.58 \\ - & 1.58 \\ - & 1.58 \\ - & 1.58 \\ - & 1.93 \\ - & 2.62 \\ - & 3.57 \\ - & 3.81 \\ - & 5.31 \\ - & 7.90 \\ - & 8.09 \\ - & 8.09 \\ - & 8.68 \\ - & 9.84 \\ - & 10.58\end{array}$

Site 708

Surface
$1 \mathrm{H}-4,145-150$
$2 \mathrm{H}-4,145-150$
$3 \mathrm{H}-4,145-150$
$4 \mathrm{H}-4,145-150$
$5 \mathrm{H}-4,145-150$
$6 \mathrm{H}-3,145-150$
$9 \mathrm{X}-1,145-150$
$12 \mathrm{X}-4,120-125$
$15 \mathrm{X}-4,120-125$
$18 \mathrm{X}-3,120-125$
$22 \mathrm{X}-4,145-150$
$24 \mathrm{X}-4,145-150$

$\begin{array}{rrr}0.0 & 0.00 & 10.25 \\ 0.5 & 5.95 & 10.37 \\ 0.7 & 14.95 & 11.18 \\ 1.1 & 24.55 & 11.59 \\ 1.7 & 34.05 & 12.45 \\ 2.6 & 43.55 & 12.24 \\ 3.3 & 51.65 & 12.88 \\ 5.0 & 77.45 & 13.30 \\ 7.5 & 107.10 & 12.90 \\ 15.0 & 136.00 & 13.04 \\ 21.6 & 162.00 & 13.49 \\ 28.5 & 203.45 & 13.58 \\ 30.0 & 222.75 & 14.10\end{array}$

$\begin{array}{rrr}53.09 & 88.0 & 554.05 \\ 54.71 & 149.6 & 567.90 \\ 53.23 & 184.4 & 587.69 \\ 51.80 & 243.8 & 583.73 \\ 52.27 & 297.1 & 586.70 \\ 51.75 & 293.0 & 589.67 \\ 51.92 & 305.3 & 586.70 \\ 51.27 & 295.1 & 592.64 \\ 50.29 & 284.8 & 588.68 \\ 49.42 & 284.8 & 580.77 \\ 49.29 & 293.0 & 565.93 \\ 48.98 & 262.3 & 566.92 \\ 48.37 & 264.3 & 581.76\end{array}$

$\begin{array}{lll}2.58 & 8.4 & 34.4 \\ 3.93 & 7.7 & 35.0 \\ 3.81 & 7.6 & 35.4 \\ 4.10 & 7.6 & 35.2 \\ 4.95 & 7.6 & 35.2 \\ 4.63 & 7.5 & 35.0 \\ 4.58 & 7.4 & 35.2 \\ 4.79 & 7.4 & 35.2 \\ 4.45 & 7.4 & 35.0 \\ 4.71 & 7.3 & 34.8 \\ 4.60 & 7.4 & 34.8 \\ 4.56 & 7.4 & 34.5 \\ 4.96 & 7.5 & 34.5\end{array}$

$\begin{array}{rcr}6 & 2.56 & 28.74 \\ 671 & 35.00 & 28.93 \\ 805 & 36.00 & 27.84 \\ 907 & 53.00 & 28.43 \\ 801 & 33.00 & 27.09 \\ 962 & 35.00 & 27.45 \\ 846 & 34.00 & 26.72 \\ 860 & 39.00 & 26.00 \\ 1000 & 45.00 & 25.45 \\ 847 & 43.00 & 24.18 \\ 860 & 31.00 & 24.91 \\ 901 & 23.00 & 23.64 \\ 1037 & & 28.36\end{array}$

$\begin{array}{lr}- & \\ 3.34 & 2.04 \\ 2.81 & 2.34 \\ 2.28 & 4.30 \\ 1.89 & 6.95 \\ 2.28 & 7.26 \\ 1.89 & 8.09 \\ 1.75 & 8.62 \\ 2.68 & 9.31 \\ 2.28 & 9.31 \\ 2.68 & 10.95 \\ 2.55 & 14.98 \\ & 15.11\end{array}$

Site 709

Surface
$1 \mathrm{H}-4,145-150$
$2 \mathrm{H}-4,145-150$
$3 \mathrm{H}-4,145-150$
$4 \mathrm{H}-3,145-150$
$6 \mathrm{H}-5,145-150$
$7 \mathrm{H}-5,145-150$
$10 \mathrm{H}-5,120-125$
$13 \mathrm{H}-5,120-125$
$16 \mathrm{H}-5,120-125$
$19 \mathrm{H}-2,140-145$
$22 \mathrm{X}-5,120-125$
$25 \mathrm{X}-4,145-150$
$28 \mathrm{X}-2,145-150$
$31 \mathrm{X}-4,145-150$
$34 \mathrm{X}-4,145-150$
$37 \mathrm{X}-4,145-150$
WS12-1
WS12-2
WS15-1
WS20-1

$\begin{array}{rrr}0.0 & 0.00 & 10.48 \\ 0.5 & 5.95 & 10.69 \\ 1.1 & 16.05 & 11.52 \\ 2.2 & 25.65 & 11.56 \\ 3.5 & 33.85 & 11.67 \\ 4.3 & 54.65 & 11.71 \\ 4.9 & 64.25 & 11.87 \\ 6.7 & 90.00 & 12.10 \\ 11.0 & 123.40 & 12.32 \\ 16.0 & 152.40 & 12.56 \\ 19.0 & 177.20 & 12.85 \\ 26.0 & 204.00 & 12.29 \\ 29.0 & 231.00 & 12.81 \\ 34.5 & 259.65 & 12.81 \\ 38.5 & 291.75 & 13.14 \\ 41.0 & 320.75 & 13.29 \\ 47.0 & 349.85 & 12.98 \\ & 102.20 & 12.96 \\ & 102.20 & 12.99 \\ & 131.10 & 13.17 \\ & 179.50 & 13.39\end{array}$

$\begin{array}{rrr}54.89 & 88.0 & 575.63 \\ 54.17 & 114.8 & 554.38 \\ 52.91 & 161.9 & 568.24 \\ 52.67 & 196.7 & 549.76 \\ 52.38 & 227.5 & 570.09 \\ 52.31 & 262.3 & 546.06 \\ 52.30 & 278.7 & 546.06 \\ 51.80 & 317.6 & 546.99 \\ 51.73 & 321.7 & 549.76 \\ 50.79 & 299.2 & 546.06 \\ 50.55 & 336.1 & 542.37 \\ 50.96 & 313.5 & 545.14 \\ 50.20 & 305.3 & 548.84 \\ 50.21 & 352.4 & 540.52 \\ 49.79 & 305.3 & 550.68 \\ 49.46 & 340.2 & 547.91 \\ 49.64 & 291.0 & 546.99 \\ 51.99 & 317.0 & 549.76 \\ 51.80 & 317.0 & 549.76 \\ 51.21 & 321.0 & 545.14 \\ 51.06 & 336.0 & 546.99\end{array}$

$\begin{array}{lll}2.52 & 8.4 & 35.0 \\ 3.42 & 7.7 & 34.5 \\ 3.66 & 7.4 & 35.0 \\ 3.82 & 7.3 & 34.9 \\ 3.78 & 7.5 & 35.2 \\ 3.96 & 7.5 & 35.1 \\ 4.03 & 7.7 & 35.1 \\ 4.25 & 7.5 & 35.2 \\ 4.31 & 7.4 & 35.2 \\ 4.42 & 7.5 & 35.0 \\ 4.53 & 7.5 & 34.8 \\ 4.09 & 7.6 & 34.4 \\ 4.29 & 7.3 & 34.4 \\ 4.59 & 7.6 & 34.4 \\ 4.50 & 7.6 & 34.5 \\ 4.50 & 7.5 & 34.8 \\ 4.22 & 7.5 & 34.9 \\ 4.90 & 7.8 & 35.0 \\ 5.02 & 7.8 & 35.0 \\ 4.90 & 7.7 & 35.5 \\ 5.12 & 7.7 & 34.9\end{array}$

$\begin{array}{rccc}0 & 0.00 & 28.98 & - \\ 610 & 0.00 & 21.12 & - \\ 710 & 4.28 & 25.12 & - \\ 753 & 12.15 & 25.82 & - \\ 683 & 5.82 & 27.22 & - \\ 764 & 7.36 & 26.94 & - \\ 784 & 32.00 & 27.50 & - \\ 822 & 11.20 & 27.92 & - \\ 574 & 18.90 & 25.20 & - \\ 402 & 18.13 & 26.94 & - \\ 562 & 11.97 & 29.13 & - \\ 687 & 22.70 & 29.44 & - \\ 835 & 37.00 & 28.50 & - \\ 845 & 38.90 & 27.02 & - \\ 942 & 29.70 & 27.15 & - \\ 849 & 38.10 & 27.36 & - \\ 759 & 15.80 & 26.59 & - \\ 680 & 18.13 & 28.36 & - \\ 670 & 26.59 & 27.28 & - \\ 335 & 22.00 & 26.61 & - \\ 596 & 45.80 & 26.21 & -\end{array}$

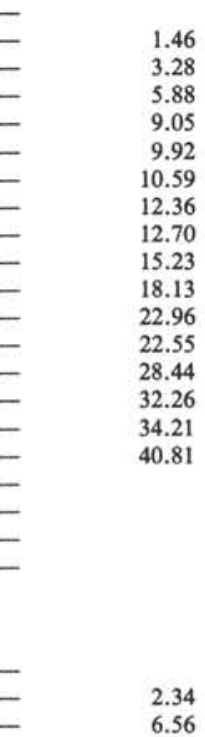

Surface $\begin{array}{rrr}0.0 & 0.00 & 10.39 \\ 0.6 & 5.95 & 11.12 \\ 1.5 & 15.45 & 11.68\end{array}$

$\begin{array}{llllll}53.53 & 86.1 & 554.33 & 2.62 & 8.4 & 34.8\end{array}$ $\begin{array}{rrr}1 & 0.00 & 29.54 \\ 631 & 7.36 & 28.42\end{array}$ 2.34
6.56 
Table 2 (continued).

\begin{tabular}{|c|c|c|c|c|c|c|c|c|c|c|c|c|c|c|}
\hline $\begin{array}{l}\text { Core, sample, } \\
\text { interval }(\mathrm{cm})\end{array}$ & $\begin{array}{l}\text { Age } \\
\text { (Ma) }\end{array}$ & $\begin{array}{l}\text { Depth } \\
\text { (mbsf) }\end{array}$ & $\begin{array}{l}\mathrm{Ca}^{2+} \\
(\mathrm{mM})\end{array}$ & $\begin{array}{r}\mathrm{Mg}^{2+} \\
(\mathrm{mM})\end{array}$ & $\begin{array}{l}\mathrm{Sr}^{2+} \\
(\mu \mathrm{M})\end{array}$ & $\begin{array}{l}\mathrm{Cl}^{-} \\
(\mathrm{mM})\end{array}$ & $\begin{array}{l}\text { Alk. } \\
(\mathrm{mM})\end{array}$ & $\mathrm{pH}$ & $\mathrm{s}$ & $\underset{(\mu \mathrm{M})}{\mathrm{Si}}$ & $\begin{array}{l}\mathrm{NH}_{4}^{+} \\
(\mu \mathrm{M})\end{array}$ & $\begin{array}{l}\mathrm{SO}_{4}^{2-} \\
(\mathrm{mM})\end{array}$ & $\begin{array}{c}\mathrm{PO}_{4}^{3-} \\
(\mu \mathrm{M})\end{array}$ & $\begin{array}{l}\text { Cumulative } \\
\text { recrystallizat }\end{array}$ \\
\hline \multicolumn{15}{|l|}{ Site 710 (Cont.) } \\
\hline $3 \mathrm{H}-2,145-150$ & 2.5 & 22.15 & 12.06 & 50.66 & 184.4 & 559.93 & 3.84 & 7.4 & 35.0 & 807 & 14.28 & 28.10 & - & 10.32 \\
\hline $4 \mathrm{H}-4,145-150$ & 4.4 & 34.75 & 12.58 & 50.60 & 207.0 & 557.13 & 3.94 & 7.4 & 35.2 & 791 & 15.05 & 28.10 & - & 13.53 \\
\hline $6 \mathrm{H}-4,145-150$ & 6.0 & 53.85 & 13.33 & 50.56 & 219.3 & 565.53 & 3.99 & 7.4 & 35.2 & 910 & 20.44 & 26.99 & - & 14.50 \\
\hline $9 \mathrm{H}-5,145-150$ & 10.2 & 83.80 & 13.75 & 50.37 & 233.6 & 554.33 & 3.92 & 7.5 & 35.2 & 885 & 35.85 & 26.03 & - & 16.41 \\
\hline $12 \mathrm{H}-5,120-125$ & 17.3 & 112.70 & 14.81 & 48.02 & 231.5 & 580.46 & 4.15 & 7.5 & 35.2 & 620 & 32.75 & 24.28 & - & 16.88 \\
\hline $15 X-3,115-125$ & 24.4 & 136.55 & 15.19 & 48.04 & 250.0 & 534.74 & 3.68 & 7.4 & 35.5 & 737 & 7.36 & 25.24 & - & 22.07 \\
\hline $18 \mathrm{X}-3,115-125$ & 28.4 & 165.55 & 15.58 & 48.21 & 254.1 & 566.47 & 3.74 & 7.5 & 35.6 & 857 & 0.43 & 24.44 & - & 22.60 \\
\hline $23 \mathrm{X}-3,115-125$ & 34.3 & 204.25 & 16.13 & 47.73 & 266.4 & 534.74 & 3.79 & 7.5 & 35.5 & 976 & 4.28 & 23.80 & - & 24.37 \\
\hline \multicolumn{15}{|l|}{ Site 711} \\
\hline Surface & 0.0 & 0.00 & 10.54 & 54.92 & 88.0 & 567.53 & 2.51 & 8.5 & 35.5 & 4 & 0.00 & 29.70 & - & \\
\hline $1 \mathrm{H}-4,145-150$ & 0.7 & 5.95 & 10.67 & 51.63 & 90.2 & 559.95 & 3.26 & 7.8 & 34.2 & 711 & 0.00 & 27.94 & - & 0.27 \\
\hline $2 \mathrm{H}-3,145-150$ & 2.4 & 12.55 & 10.86 & 52.08 & 94.3 & 553.32 & 3.36 & 7.7 & 35.2 & 668 & 0.00 & 28.58 & - & 1.40 \\
\hline $3 \mathrm{H}-4,145-150$ & 5.3 & 23.65 & 10.89 & 51.24 & 90.2 & 567.53 & 3.45 & 7.7 & 35.0 & 700 & 0.00 & 28.74 & - & 2.55 \\
\hline $4 \mathrm{H}-5,145-150$ & 7.9 & 34.75 & 11.12 & 51.82 & 94.3 & 565.63 & 3.42 & 7.7 & 35.0 & 688 & 0.00 & 28.34 & - & 3.58 \\
\hline $5 \mathrm{H}-5,145-150$ & 11.0 & 44.35 & 11.44 & 51.74 & 96.3 & 568.47 & 4.02 & 7.7 & 35.0 & 472 & 0.00 & 27.70 & - & 4.29 \\
\hline $6 \mathrm{H}-5,115-120$ & 17.5 & 53.75 & 11.13 & 51.16 & 98.4 & 574.16 & 3.85 & 7.6 & 34.6 & 370 & 0.00 & 27.06 & - & 5.81 \\
\hline $9 \mathrm{H}-5,115-120$ & 25.7 & 82.75 & 11.44 & 50.92 & 106.6 & 559.00 & 3.69 & 7.6 & 35.0 & 520 & 0.00 & 26.98 & - & 8.30 \\
\hline $12 \mathrm{X}-2,115-120$ & 29.5 & 107.15 & 11.50 & 50.94 & 110.7 & 579.84 & 3.76 & 7.5 & 34.8 & 661 & 0.00 & 26.74 & - & 8.98 \\
\hline $15 X-5,115-120$ & 35.0 & 140.75 & 12.19 & 51.07 & 106.6 & 568.47 & 3.79 & 7.5 & 35.0 & 741 & 0.00 & 27.38 & - & 9.70 \\
\hline $18 \mathrm{X}-3,140-145$ & 37.5 & 167.10 & 12.48 & 50.29 & 110.7 & 542.89 & 4.08 & 7.6 & 35.2 & 797 & 0.00 & 26.98 & - & 10.12 \\
\hline $21 \times-4,140-145$ & 45.0 & 197.60 & 12.60 & 50.32 & 125.0 & 552.37 & 4.12 & 7.6 & 35.0 & 835 & 0.00 & 27.38 & - & 13.90 \\
\hline $24 \mathrm{X}-3,140-145$ & 48.0 & 225.10 & 12.86 & 50.37 & 127.0 & 552.37 & 4.12 & 7.7 & 35.2 & 833 & 0.00 & 26.65 & - & 14.14 \\
\hline \multicolumn{15}{|l|}{ Site 712} \\
\hline Surface & 0.0 & 0.00 & - & - & - & 561.84 & 2.51 & 8.5 & 35.5 & - & 0.0 & 29.15 & - & \\
\hline $1 \mathrm{R}-5,145-150$ & 0.8 & 7.45 & 10.51 & 53.16 & 88.1 & 548.58 & 2.90 & 7.8 & 35.0 & 449 & 77.0 & 28.55 & - & \\
\hline $2 \mathrm{R}-4,145-150$ & 1.7 & 15.48 & 10.57 & 52.85 & 90.2 & 551.42 & 3.03 & 7.7 & 35.2 & 594 & 190.0 & 28.12 & - & 0.13 \\
\hline $3 \mathrm{R}-3,140-150$ & 2.5 & 23.4 & 10.51 & 53.08 & 94.3 & 567.53 & 3.05 & 7.7 & 35.2 & 655 & 69.0 & 28.11 & - & 0.38 \\
\hline $4 \mathrm{R}-2,140-150$ & 8.2 & 31.5 & 10.76 & 54.28 & 98.4 & 572.26 & 2.98 & 7.8 & 35.8 & 605 & 71.0 & 28.60 & - & 2.20 \\
\hline $6 \mathrm{R}-2,140-150$ & 13.5 & 50.8 & 11.58 & 52,80 & 106.6 & 557.11 & 3.01 & 7.8 & 35.2 & 615 & 44.0 & 28.31 & - & 3.54 \\
\hline \multicolumn{15}{|l|}{ Site 713} \\
\hline $2 \mathrm{R}-4,145-150$ & 1.4 & 7.55 & 11.10 & 53.53 & 106.6 & 571.32 & 3.07 & 7.8 & 35.0 & 497 & 40.0 & 28.51 & - & \\
\hline $3 \mathrm{R}-4,145-150$ & 3.1 & 17.15 & 11.47 & 53.24 & 112.7 & 565.63 & 3.00 & 7.7 & 35.5 & 577 & 72.0 & 28.17 & - & 0.69 \\
\hline $4 \mathrm{R}-2,140-150$ & 4.9 & 26.75 & 11.46 & 52.11 & 114.7 & 557.11 & 2.91 & 7.7 & 35.0 & 756 & 65.0 & 27.44 & - & 0.93 \\
\hline $5 \mathrm{R}-2,145-150$ & 41.0 & 33.45 & 11.80 & 51.12 & 118.8 & 560.89 & 2.77 & 7.5 & 35.0 & 775 & 50.0 & 27.72 & - & 22.59 \\
\hline $6 \mathrm{R}-2,145-150$ & 41.5 & 43.05 & 12.12 & 51.21 & 118.8 & 570.37 & 2.63 & 7.5 & 35.0 & 743 & 43.0 & 28.24 & - & 22.59 \\
\hline $9 \mathrm{R}-1,145-150$ & 45.0 & 70.55 & 13.44 & 50.77 & 122.9 & 565.63 & 2.54 & 7.7 & 35.2 & 554 & 46.0 & 27.80 & - & 23.31 \\
\hline $12 \mathrm{R}-1,147-150$ & 45.5 & 99.57 & 14.02 & 49.14 & 122.9 & 558.05 & 1.78 & 8.0 & 35.0 & 630 & 52.0 & 27.22 & - & 23.31 \\
\hline $17 \mathrm{R}-3,150-155$ & 48.0 & 150.22 & 20.36 & 39.32 & 120.9 & 571.32 & 1.10 & 8.1 & 34.8 & 279 & 41.0 & 26.19 & - & 23.37 \\
\hline
\end{tabular}

Site 714

Surface
$1 \mathrm{H}-1,145-150$
$2 \mathrm{H}-4,145-150$
$3 \mathrm{H}-4,145-150$
$4 \mathrm{H}-5,145-150$
$5 \mathrm{H}-5,145-150$
$6 \mathrm{H}-4,145-150$
$9 \mathrm{H}-2,145-150$
$12 \mathrm{H}-4,120-125$
$15 \mathrm{X}-3,120-125$
$18 \mathrm{X}-4,120-125$
$22 \mathrm{X}-4,120-125$
$25 \mathrm{X}-1,145-150$

$\begin{array}{rrr}0.0 & 0.00 & 10.59 \\ 0.0 & 1.45 & 10.58 \\ 0.2 & 8.75 & 10.68 \\ 0.5 & 18.35 & 10.64 \\ 8.0 & 28.08 & 10.79 \\ 9.0 & 39.15 & 10.76 \\ 9.5 & 47.35 & 10.90 \\ 11.0 & 73.15 & 10.87 \\ 14.5 & 104.80 & 10.95 \\ 16.0 & 131.00 & 11.20 \\ 17.3 & 161.40 & 11.01 \\ 22.0 & 200.10 & 11.38 \\ 28.2 & 224.75 & 11.62\end{array}$

$\begin{array}{rrr}55.21 & 90.2 & 577.00 \\ 51.22 & 92.2 & 540.05 \\ 52.14 & 127.0 & 578.90 \\ 52.23 & 151.6 & 544.79 \\ 52.17 & 147.5 & 581.74 \\ 52.11 & 159.8 & 576.05 \\ 51.90 & 151.6 & 565.63 \\ 50.71 & 163.9 & 572.26 \\ 49.99 & 172.1 & 559.00 \\ 50.05 & 192.6 & 552.37 \\ 50.64 & 176.2 & 558.05 \\ 50.77 & 161.9 & 560.89 \\ 52.55 & 139.3 & 570.37\end{array}$

$\begin{array}{llll}2.47 & 8.5 & 35.4 & \\ 3.30 & 7.6 & 35.2 & \\ 3.88 & 7.5 & 35.2 & 621 \\ 4.32 & 7.6 & 34.8 & 663 \\ 4.08 & 7.5 & 35.5 & \\ 4.44 & 7.6 & 35.2 & \\ 4.23 & 7.6 & 35.4 & 704 \\ 3.99 & 7.7 & 35.0 & 769 \\ 4.19 & 7.6 & 35.2 & 783 \\ 4.00 & 7.5 & 35.2 & 797 \\ 3.78 & 7.5 & 34.8 & \\ 3.63 & 7.6 & 35.2 & \\ 3.36 & 7.8 & 35.8 & 771\end{array}$

-
575
621
663
746
568
704
769
783
797
808
870
771

$\begin{array}{cc}0.0 & 29.48 \\ 46.5 & 27.46 \\ 112.0 & 26.51 \\ 135.0 & 26.88 \\ 106.0 & 27.03 \\ 125.0 & 27.17 \\ 114.0 & 26.51 \\ 111.0 & 26.30 \\ 129.0 & 26.29 \\ 112.0 & 26.64 \\ 94.0 & 26.42 \\ 69.0 & 26.67 \\ 42.0 & 26.46\end{array}$

$\begin{array}{ll}1.85 & \\ 6.99 & 0.04 \\ 6.22 & 0.73 \\ 4.16 & 1.15 \\ 2.62 & 3.28 \\ 3.78 & 3.98 \\ 2.36 & 4.35 \\ 2.24 & 4.77 \\ 2.49 & 5.37 \\ 2.11 & 6.16 \\ 2.24 & 6.60 \\ 1.98 & 7.78 \\ 1.98 & 11.58\end{array}$

Site 715

Surface
$1 \mathrm{R}-3,145-150$
$2 \mathrm{R}-4,145-150$
$3 \mathrm{R}-4,145-150$
$4 \mathrm{R}-4,145-150$
$5 \mathrm{R}-4,145-150$
$6 \mathrm{R}-4,145-150$
$9 \mathrm{R}-4,145-150$

$\begin{array}{rrr}0.0 & 0.00 & - \\ 0.1 & 4.45 & 10.28 \\ 0.2 & 14.05 & 10.54 \\ 0.3 & 23.75 & 10.54 \\ 0.4 & 33.45 & 10.63 \\ 0.5 & 43.05 & 10.50 \\ 12.0 & 52.75 & 10.67 \\ 15.0 & 81.65 & 10.62\end{array}$

51.84
52.55
52.95
53.42
52.01
53.15
53.28

$\begin{array}{rr}- & 577.00 \\ 86.1 & 552.48 \\ 94.3 & 556.21 \\ 100.4 & 545.96 \\ 110.7 & 540.37 \\ 110.7 & 562.73 \\ 110.7 & 545.96 \\ 102.5 & 564.59\end{array}$

$\begin{array}{lll}2.47 & 8.5 & 35.4 \\ 3.38 & 7.8 & 34.4 \\ 3.97 & 7.7 & 34.5 \\ 4.20 & 7.5 & 34.2 \\ 4.38 & 7.5 & 35.0 \\ 4.40 & 7.3 & 34.8 \\ 4.33 & 7.6 & 34.5 \\ 3.45 & 7.8 & 35.0\end{array}$

$\begin{array}{ccc}\overline{671} & 3.7 & 27.80 \\ 662 & 163.0 & 27.25 \\ 727 & 174.0 & 26.37 \\ 702 & 165.0 & 26.70 \\ 783 & 188.0 & 26.70 \\ 714 & 133.0 & 26.50 \\ 479 & 108.0 & 27.48\end{array}$

3.76

13.55

12.07
10.04

10.05

12.63

10.23
7.27

0.27
1.40
2.55
3.58
4.29
5.81
8.30
8.98
9.70
0.12
3.90
4.14

Site 716

Surface
$1 \mathrm{H}-3,145-150$
$2 \mathrm{H}-4,145-150$
$3 \mathrm{H}-4,120-125$

$\begin{array}{rrr}0.0 & 0.00 & 10.43 \\ 0.3 & 4.45 & 10.71 \\ 0.5 & 12.85 & 10.77 \\ 0.7 & 22.20 & 10.70\end{array}$

54.37

$\begin{array}{lllll}90.2 & 535.31 & 2.53 & 8.5 & 34.5\end{array}$

$\begin{array}{llllll}53.11 & 102.5 & 538.16 & 2.90 & 7.9 & 34.2\end{array}$

$\begin{array}{llllll}54.00 & 118.6 & 544.79 & 2.95 & 7.5 & 35.0 \\ & 550.47 & 3.00 & 7.6 & 34.8\end{array}$

-
78
81

$\begin{array}{ll}81.4 & 27.17 \\ 75.7 & 28.58 \\ 93.0 & 25.73\end{array}$

2.47
3.21
2.47
3.39

0.28

0.32

0.38 
Table 2 (continued).

\begin{tabular}{|c|c|c|c|c|c|c|c|c|c|c|c|c|c|c|}
\hline $\begin{array}{l}\text { Core, sample, } \\
\text { interval }(\mathrm{cm})\end{array}$ & $\begin{array}{l}\text { Age } \\
\text { (Ma) }\end{array}$ & $\begin{array}{l}\text { Depth } \\
\text { (mbsf) }\end{array}$ & $\begin{array}{l}\mathrm{Ca}^{2+} \\
(\mathrm{mM})\end{array}$ & $\begin{array}{l}\mathrm{Mg}^{2+} \\
(\mathrm{mM})\end{array}$ & $\begin{array}{l}\mathrm{Sr}^{2+} \\
(\mu \mathrm{M})\end{array}$ & $\begin{array}{l}\mathrm{Cl}^{-} \\
(\mathrm{mM})\end{array}$ & $\begin{array}{l}\text { Alk. } \\
\text { (mM) }\end{array}$ & $\mathrm{pH}$ & $\mathrm{s}$ & $\begin{array}{c}\mathrm{Si} \\
(\mu \mathrm{M})\end{array}$ & $\begin{array}{l}\mathrm{NH}_{4}^{+} \\
(\mu \mathrm{M})\end{array}$ & $\begin{array}{l}\mathrm{SO}_{4}^{2-} \\
(\mathrm{mM})\end{array}$ & $\begin{array}{c}\mathrm{PO}_{4}^{3-} \\
(\mu \mathrm{M})\end{array}$ & $\begin{array}{l}\text { Cumulative \% } \\
\text { recrystallization }\end{array}$ \\
\hline \multicolumn{15}{|l|}{ Site 716 (Cont.) } \\
\hline $4 \mathrm{H}-4,145-150$ & 0.8 & 32.05 & 10.88 & 54.05 & 135.2 & 534.37 & 3.15 & 8.0 & 35.0 & 96 & 109.0 & 28.61 & 3.39 & 0.42 \\
\hline $5 \mathrm{H}-4,145-150$ & 1.0 & 41.75 & 10.88 & 54.46 & 135.2 & 531.52 & 3.00 & 7.7 & 35.2 & 86 & 110.0 & 29.00 & 3.39 & 0.42 \\
\hline $6 \mathrm{H}-4,120-125$ & 1.4 & 51.20 & 11.19 & 53.54 & 182.4 & 546.68 & 3.19 & 7.7 & 35.5 & 90 & 102.0 & 28.74 & 5.05 & 1.02 \\
\hline $9 \mathrm{H}-4,120-125$ & 2.4 & 80.00 & 12.90 & 53.14 & 383.2 & 564.68 & 4.69 & 7.6 & 35.5 & 0 & 252.0 & 28.54 & 5.79 & 3.79 \\
\hline $12 \mathrm{H}-4,120-125$ & 3.6 & 108.90 & 14.51 & 51.14 & 471.3 & 541.95 & 5.11 & 7.6 & 35.2 & 448 & 275.0 & 27.86 & 6.35 & 7.82 \\
\hline $15 \mathrm{H}-4,120-125$ & 4.2 & 137.80 & 16.05 & 47.55 & 487.7 & 533.42 & 5.74 & 7.5 & 35.2 & 362 & 286.0 & 27.87 & 8.01 & 8.94 \\
\hline $18 \mathrm{H}-4,120-125$ & 4.6 & 166.65 & 16.72 & 46.46 & 497.9 & 536.26 & 5.49 & 7.4 & 34.2 & 534 & 451.0 & 26.22 & 9.67 & 9.38 \\
\hline $21 \mathrm{H}-4,115-125$ & 5.4 & 195.75 & 17.26 & 46.65 & 512.3 & 536.26 & 5.92 & 7.3 & 35.2 & 686 & 334.0 & 26.99 & 14.3 & 11.14 \\
\hline $24 \mathrm{H}-4,140-150$ & 6.1 & 225.10 & - & - & - & 531.52 & 5.80 & 7.3 & 34.8 & 1004 & 358.0 & 26.27 & 17.25 & 12.49 \\
\hline $27 \mathrm{H}-4,140-150$ & 6.5 & 254.00 & 17.68 & 46.02 & 473.3 & 540.05 & 6.05 & 7.3 & 34.8 & 774 & 388.0 & 26.41 & 13.55 & 12.93 \\
\hline
\end{tabular}

Note: Dash $(-)$ indicates that no analyses were performed.

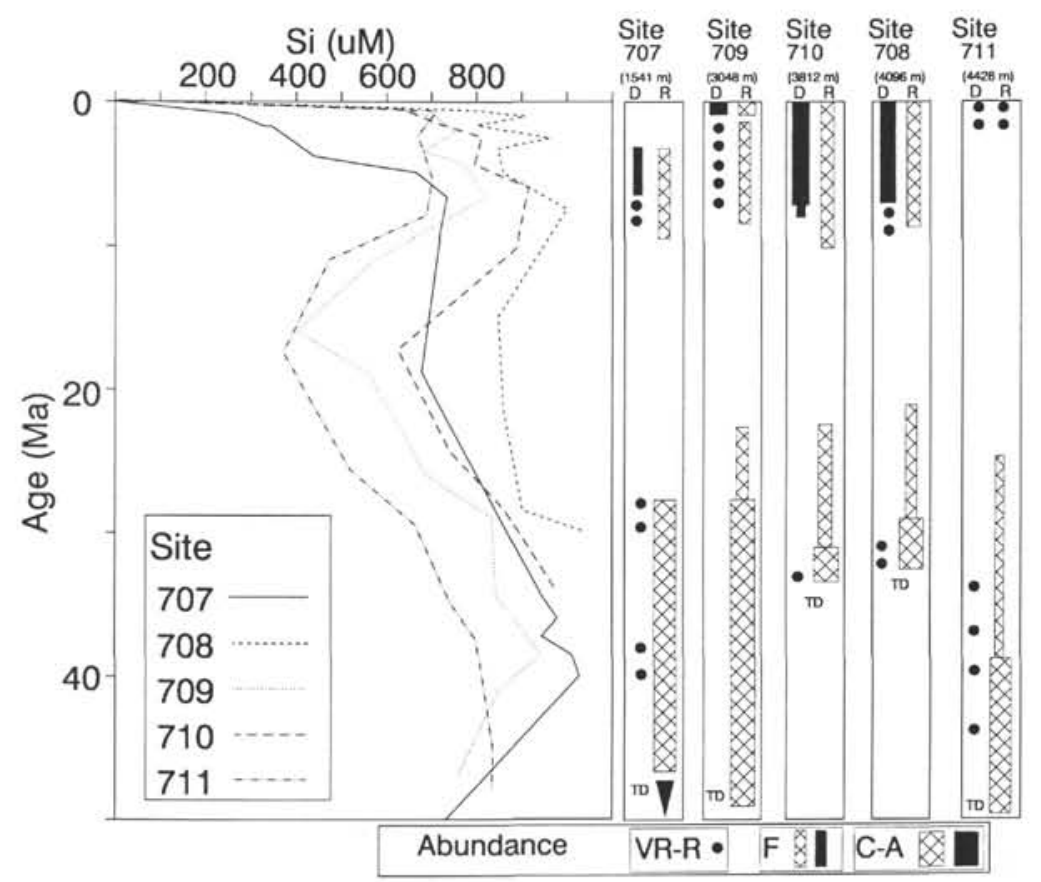

Figure 5. Pore-water Si profiles and distribution of diatoms (D, solid bars), and radiolarians ( $R$, stippled bars) in Sites 707 through 711 (data for Si distribution is from Mikkelsen, this volume). The $\mathrm{Si}$ data for Site 707 have been compiled from Holes $707 \mathrm{~A}$ and $707 \mathrm{C}$, and the data for Site 709, from Holes 709B and 709C. Note the decrease in the pore-water $\mathrm{Si}$ concentration between 15 and $20 \mathrm{Ma}$.

exception of Site 716, where very small increases were noted. As a consequence of the low concentrations of organic matter, changes in the concentration of alkalinity, $\mathrm{pH}$, phosphate, and ammonia were extremely low at all sites. Alkalinity generally increased downcore.

The highest amounts of sulfate reduction occurred at Sites 709 and 716 and are associated with small increases in phosphate, ammonia, and alkalinity. Site 716 also exhibited the highest concentration of organic material and showed evidences of methane (Backman, Duncan, et al., 1988). Changes in the concentration of sulfate associated with increases in ammonia were observed at Sites 708, 709, and 710. Samples retrieved using the Barnes downhole water sampler at Site 709 contained excess alkalinity compared with waters squeezed from sediments from comparable depth intervals.

\section{Solids}

The X-ray mineralogy of all samples showed them to consist largely of low- $\mathrm{Mg}^{2+}$ calcite. The exception to this was at Site 708 , where small quantities of aragonite were detected and at Site 716, which is composed of periplatform sediments (Backman, Duncan, et al., 1988). At Site 716, the concentrations of aragonite decrease from approximately $30 \%$ to less than $5 \%$ by $50 \mathrm{mbsf}$ (Malone et al., this volume; Droxler et al., this volume).

\section{Strontium}

The $\mathrm{Sr}$ concentrations of the $<63-$ and $>63-\mu \mathrm{m}$ fractions, together with their percentages, are shown in Figure 6 and Table 2 . There do not appear to be any systematic differences in the $\mathrm{Sr}$ 

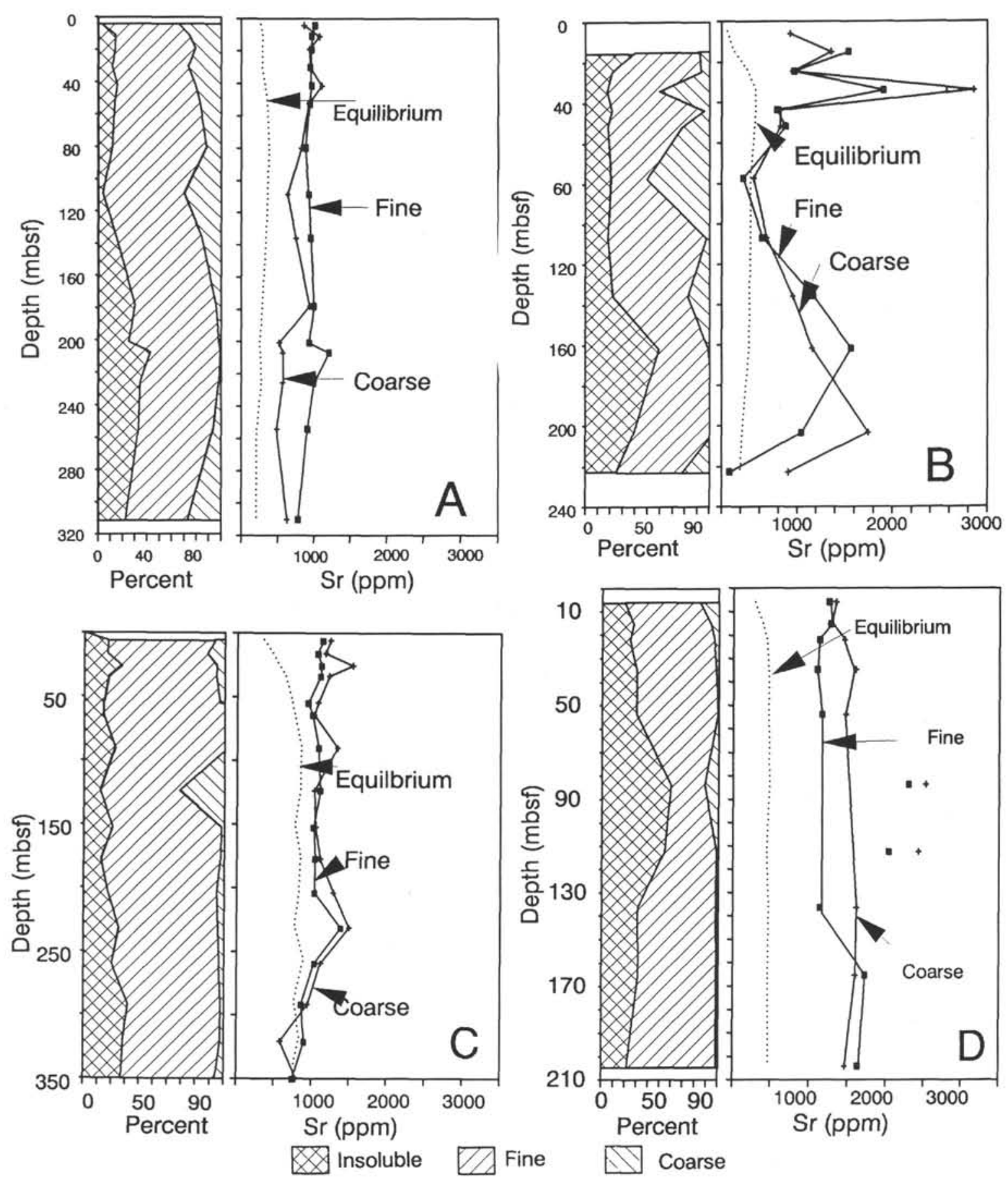

Figure 6. Concentration of $\mathrm{Sr}^{2+}$ in fine and coarse fraction, as well as predicted equilibrium concentration using a $D_{\mathrm{Sr}}$ of 0.037 (Baker et al., 1982). (A) Site 707, (B) Site 708, (C) Site 709, (D) Site 710, (E) Site 711, and (F) Site 716. In the profile at Site 710, two data points have been omitted from the trend. These correspond to samples with excess amounts of insoluble material and therefore may have given incorrect $\mathrm{Sr}$ values.

concentration between the coarse and fine fractions. In several of the "carbonate" sites, high concentrations of $\mathrm{Sr}$ suggest the presence of small amounts of aragonite (Site 708 and 711). In all sites other than Site $716, \mathrm{Sr}$ concentrations do not exhibit any systematic trend with increasing sub-bottom depth. There is, however, a large amount of variability in the strontium content of all the solid samples, but it does not show any consistent trend in concentration downhole. The only exception occurs in Hole $709 \mathrm{C}$, in which there is a slight decrease at the bottom of the hole, and in Site 716, where the initial sediment consists of mixtures of bank-derived, Sr-rich aragonite and high-Mg calcite, as well as low-Mg calcite.

Finally, we note that values for the $\mathrm{Sr}$ concentration of the fine fraction measured in the upper portion of Site 709 sediments were significantly lower than data reported for the same sediments by Baker et al. (this volume). In the lower portion of Site 709, data concurs between this study and that of Baker et al. (this volume). Our data for Site 715 also agrees with that of 


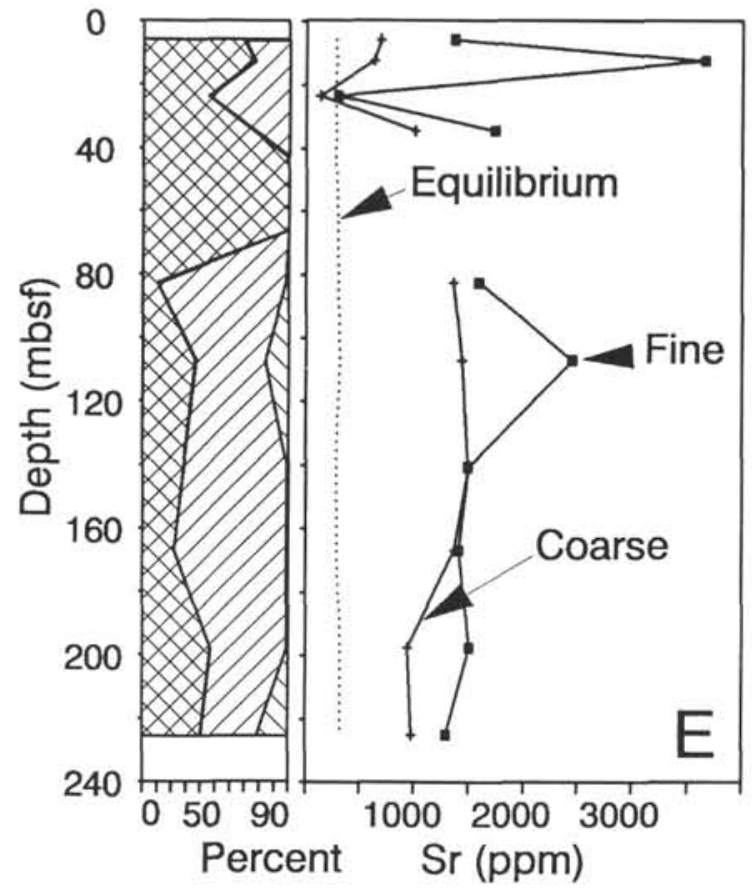

X Insoluble
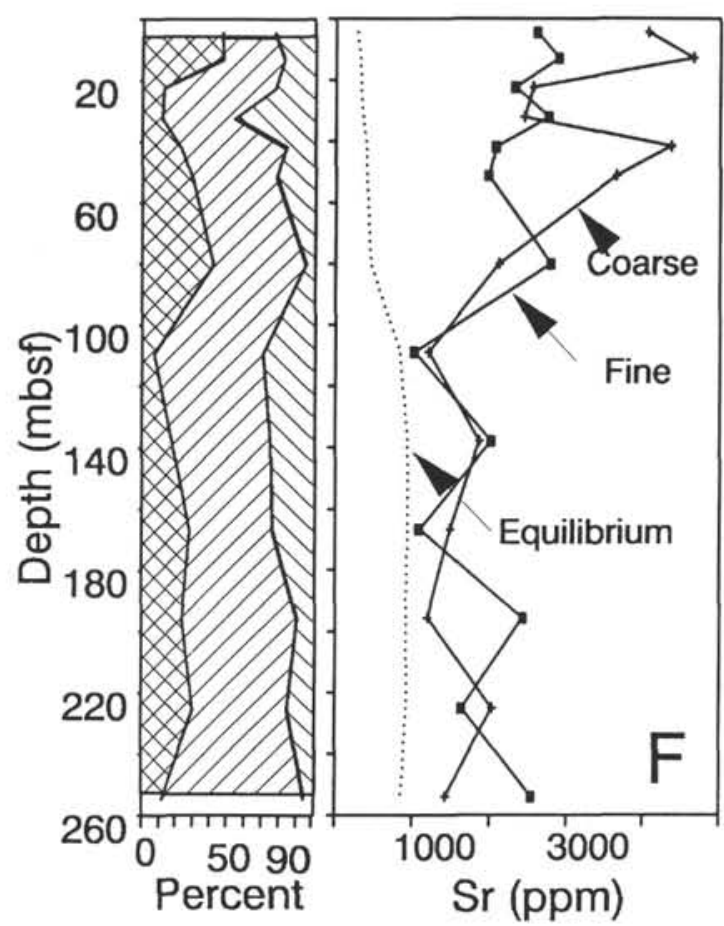

Coarse

Figure 6 (continued).

Malone et al. (this volume), the samples of which were prepared similarly to those of Baker et al., and measured in the same laboratory. We have no explanation for this discrepancy at the present time and can only speculate that it represents some systematic difference in preparation method carried out by the respective laboratories.

\section{DISCUSSION}

\section{Rates of Recrystallization}

\section{Interstitial Strontium Concentrations}

All sites examined from Leg 115 showed modest increases in the dissolved $\mathrm{Sr}^{2+}$ concentration of the interstitial fluid downcore (Fig. 3). Such increases have been shown at other DSDP and ODP sites to be a result of the recrystallization of biogenic calcite to inorganic calcite and aragonite, with the consequent release of $\mathrm{Sr}^{2+}$ to the pore fluids (Baker et al., 1982). At sites where the $\mathrm{Sr}^{2+}$ and $\mathrm{SO}_{4}^{2-}$ concentrations are below celestite saturation, the diffusive flux of $\mathrm{Sr}^{2+}$ from the sediments can be calculated and an estimate of recrystallization obtained (Baker, 1986; Stout, 1985a, 1985b; Swart and Guzikowski, 1988). Such a technique would only be valid in the absence of advective flow through the sediments (see later discussion). Since all Leg 115 sites, apart from Site 716 (Fig. 4), fulfill this condition, we have estimated recrystallization with the method outlined by Baker (1986) (Table 2 and Fig. 7).

In this method, the $\mathrm{Sr}$ flux out or into the sediments, given by Equation 1, is summed over the time interval represented by two successive pore-water samples. If the $\mathrm{Sr}$ content decreases, we have assumed there is some sink for $\mathrm{Sr}$ in the sediments, and this flux is therefore counted as a loss of $\mathrm{Sr}^{2+}$.

$$
\text { Flux }=-D_{b} \partial c / \partial x,
$$

where $D_{b}=$ diffusion coefficient $\left(4 \times 10^{-6} \mathrm{~cm}^{2} / \mathrm{s}\right), \partial c=$ concentration gradient, and $\partial x=$ depth interval in question.

If it is assumed that the average $\mathrm{Sr} / \mathrm{Ca}$ molar ratio of the sediment is $2 \times 10^{-3}$, a typical value for pelagic calcite (Baker, 1986), then the total amount of $\mathrm{Sr}$ in the sediment in each interval can be calculated using the percent insoluble data shown in Table 3. If any carbonate is initially present which contains a higher $\mathrm{Sr} / \mathrm{Ca}$ ratio, for example, aragonite in Site 716, the calculated rate will be lower; therefore, for this site we have used a $\mathrm{Sr} / \mathrm{Ca}$ ratio of $4 \times 10^{-3}$. This reflects a mixture of aragonite with a Sr/Ca ratio of $9 \times 10^{-3}$ and LMC. The total amount of $\mathrm{Sr}$ lost is then compared with the amount of $\mathrm{Sr}$ available in the sediment. The percentage of the amount of $\mathrm{Sr}$ lost compared to $\mathrm{Sr}$ available yields the amount of recrystallization that has occurred over the time interval represented by the sampling interval. Assuming that the present pore-water profile has remained approximately the same over time, the total amount of recrystallization of a particular interval can be obtained by summing all the intervals over which pore-water data are available. These data are shown in Table 2 and Figure 7.

This approach suggests that the maximum rate of recrystallization occurs in the upper $50 \mathrm{~m}$ of the core, the rate decreasing with increasing depth sub-bottom. Of the "carbonate" sites, low rates of recrystallization are shown at Sites 707 and 711, the shallowest and deepest sites $(1541.4 \mathrm{~m}$ and $4428.2 \mathrm{~m}$ respectively). At Site 707, the maximum amount of recrystallization is approximately $11 \%$ in sediments of $55 \mathrm{Ma}$. The similar rates of recrystallization at Site 711 compared to the shallowest site, Site 707, result from the fact that Site 711 is situated below the present-day CCD and, therefore, substantial dissolution of the most reactive calcium carbonate has occurred on the sea floor before burial. The highest initially calculated rates of recrystallization occurs in sites at intermediate depths, such as Sites 709 


\section{Recrystallization \%}

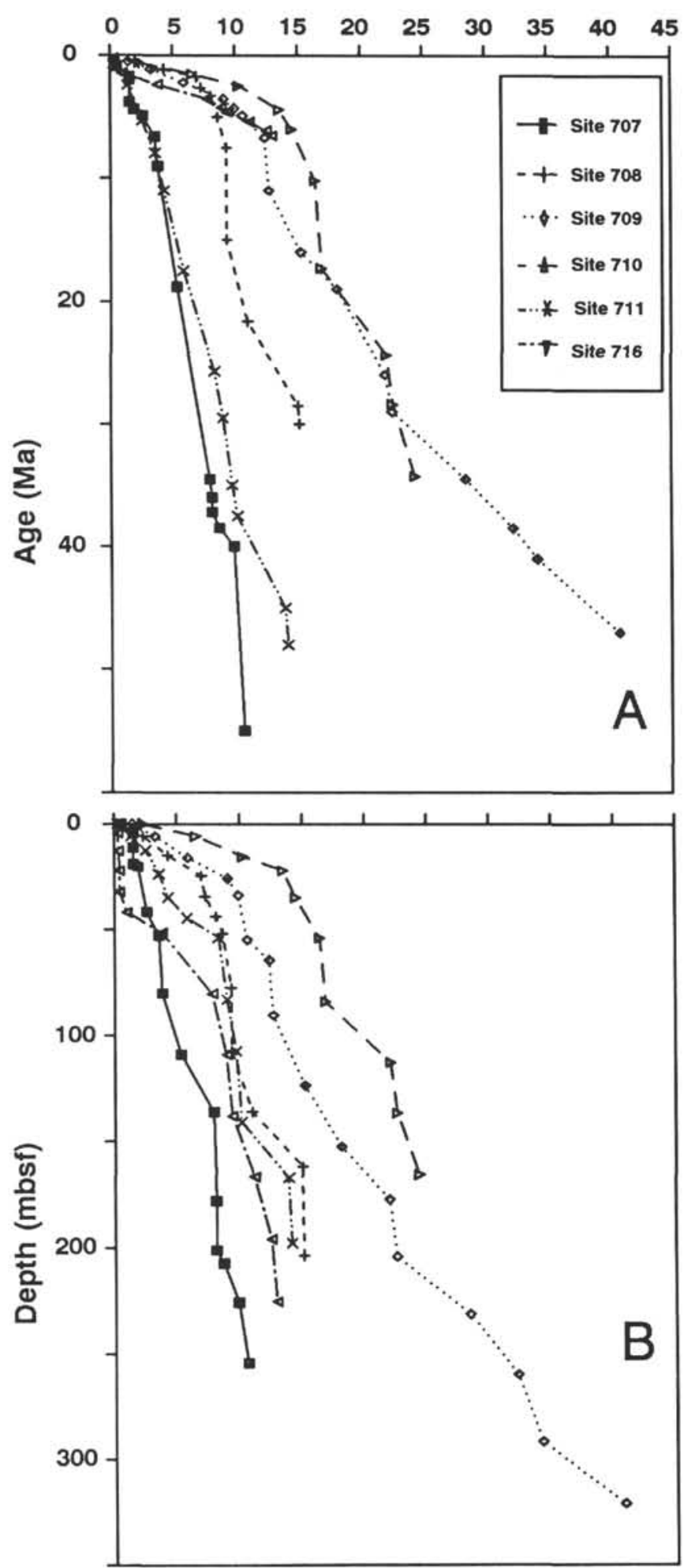

Figure 7. Cumulative percent recrystallization estimates based on $\mathrm{Sr}^{2+}$ flux for Sites 707-711, with respect to age (A) and depth (B). and 710 . Of these, Site 710 exhibits the highest initial rates of recrystallization, reaching $27 \%$ by 204.25 mbsf in sediments of 34.3 Ma. Site 709 has the highest overall percentage of recrystallization, $43 \%$ by a depth of 349.85 mbsf. Progressively lower rates of recrystallization occur in the deeper sites (Sites 708 and 711 , probably a consequence of the greater amounts of dissolution occurring at the seafloor as in the case of Site 711 .

Surprisingly, comparable rates of recrystallization were measured at Site 716, the site that contains periplatform sediments and large concentrations of metastable aragonite. This is similar to results from Leg 101, which were obtained using the Sr flux method for estimating recrystallization (Swart and Guzikowski, 1988). The precise reasons for the low calculated rates of recrystallization are uncertain, as the decrease in the concentration of aragonite between the sediment surface and $50 \mathrm{mbsf}(>30 \%$ to $<5 \%$ ), noted by Malone et al. (this volume), has been interpreted as being the result of recrystallization. One possible explanation would be that the method used in this paper to calculate the $\mathrm{Sr}$ gradient in the zone of celestite saturation underestimates the amount of $\mathrm{Sr}$ lost as celestite. The percent recrystallization $(\% \mathrm{R})$ shown in Figure 2 and Table 2 for the depths that are above celestite saturation have been extrapolated from the strontium gradient between 51.2 and 80 mbsf (Fig. 4). It is also possible that either the decrease in aragonite noted by Malone et al. (this volume) results from a decrease in the input of aragonite from the bank and is therefore not diagenetic, or that significant amounts of aragonite dissolution are occurring on the seafloor before burial. If either of these last scenarios were applicable, the initial $\mathrm{Sr}$ concentration used in the calculations shown in Figure 7 would need to be lowered for Site 716. Consequently, higher rates of recrystallization would be calculated.

\section{Oxidation of Organic Material}

A significant factor in determining rates of recrystallization of carbonate sediments is the amount of organic material that is buried with the sediment. Organic material, if present, normally becomes oxidized by an electron acceptor such as oxygen or sulfate, liberating $\mathrm{CO}_{2}$ thereby promoting recrystallization of the biogenic carbonate. Although all sites drilled during Leg 115 (with the exception of Site 716) contained extremely low concentrations of organic material (Backman, Duncan, et al., 1988 ), it is possible that small differences in the quantities of organic material between the "carbonate" sites could have been responsible for the observed differences in recrystallization between sites. For example, Site 707, which showed no decreases in the concentration of interstitial sulfate, accordingly had the lowest rates of recrystallization. Sites 708,709 , and 710 , however, did exhibit decreases in sulfate, the lowest value $(21.12$ $\mathrm{mM}$ ) occurring at Site 709 at 5.95 mbsf. These sites accordingly have higher calculated rates of recrystallization.

The method of estimating recrystallization from the $\mathrm{Sr}^{2+}$ flux provides only a minimum estimate of recrystallization, since it makes no assumption for the incorporation of $\mathrm{Sr}^{2+}$ into calcite. In order to constrain the possible effect of precipitation on the concentration of $\mathrm{Sr}^{2+}$, it is possible to estimate the amount of net precipitation from the increase in alkalinity. Generally, changes in alkalinity are related to either the oxidation of organic material by sulfate reduction, through a reaction similar to the following equation:

$$
\begin{aligned}
53 \mathrm{SO}_{4}^{2-}+\mathrm{C}_{106} \mathrm{H}_{263} \mathrm{O}_{110} \mathrm{~N}_{16} \mathrm{P}= & 106 \mathrm{HCO}_{3}^{-}+16 \mathrm{NH}_{3} \\
& +53 \mathrm{H}_{2} \mathrm{~S}+\mathrm{H}_{3} \mathrm{PO}_{4}
\end{aligned}
$$

or through the dissolution of carbonate minerals such as calcite and aragonite. As noted in the "Results" in this chapter, increases in alkalinity were observed in most of the sites investi- 
Table 3. The concentration of $\mathrm{Sr}$ in the coarse and fine fractions from the sediment from which waters were squeezed in Leg 115.

\begin{tabular}{|c|c|c|c|c|c|c|c|}
\hline \multirow[t]{2}{*}{$\begin{array}{l}\text { Core, sample, } \\
\text { interval }(\mathrm{cm})\end{array}$} & \multirow[t]{2}{*}{$\begin{array}{l}\text { Depth } \\
\text { (mbsf) }\end{array}$} & \multicolumn{3}{|c|}{$\begin{array}{l}\text { Sr concentration } \\
\text { solid (ppm) }\end{array}$} & \multicolumn{3}{|c|}{ Percentage of sediment } \\
\hline & & $>62$ & $<62$ & Equil. & $>62$ & $<62$ & Insoluble \\
\hline $115-705 \mathrm{~A}-1 \mathrm{H}-3,145-150$ & 4.45 & 1168 & 861 & - & 37.70 & 59.64 & 0.00 \\
\hline $115-705 \mathrm{~A}-2 \mathrm{H}-3,145-150$ & 12.95 & 1070 & 807 & - & 30.50 & 66.32 & 0.00 \\
\hline $115-706 \mathrm{~A}-2 \mathrm{H}-5,145-150$ & 9.95 & 1123 & 743 & 256 & 2.50 & 94.65 & 23.02 \\
\hline $115-706 \mathrm{~A}-3 \mathrm{H}-4,145-150$ & 18.15 & 1121 & 664 & 240 & 1.58 & 96.45 & 16.34 \\
\hline $115-706 \mathrm{~A}-4 \mathrm{H}-3,145-150$ & 26.35 & 1087 & 716 & 223 & 2.41 & 95.42 & 16.80 \\
\hline $115-706 \mathrm{~A}-5 \mathrm{H}-4,145-150$ & 37.45 & 1210 & 893 & 205 & 1.23 & 97.26 & 26.40 \\
\hline $115-706 \mathrm{~A}-6 \mathrm{H}-2,145-150$ & 44.05 & 1119 & 555 & 201 & 0.61 & * & 46.32 \\
\hline $115-707 \mathrm{~A}-1 \mathrm{H}-3,145-150$ & 4.45 & 1015 & 862 & 274 & 32.05 & 64.68 & 0.00 \\
\hline $115-707 \mathrm{~A}-2 \mathrm{H}-5,145-150$ & 11.05 & 968 & 1075 & 298 & 27.23 & 14 & 22.00 \\
\hline $115-707 \mathrm{~A}-3 \mathrm{H}-3,145-150$ & 19.15 & 965 & 935 & 292 & 18.89 & 75.53 & 18.00 \\
\hline $115-707 \mathrm{~A}-4 \mathrm{H}-3,145-150$ & 30.25 & 948 & 947 & 286 & 28.16 & 69.90 & 15.54 \\
\hline $115-707 \mathrm{~A}-5 \mathrm{H}-4,145-150$ & 41.45 & 965 & 1113 & 332 & 20.89 & 75.32 & 20.24 \\
\hline $115-707 \mathrm{~A}-6 \mathrm{H}-5,145-150$ & 52.55 & 940 & 926 & 361 & 16.39 & 80.51 & 16.34 \\
\hline $115-707 \mathrm{~A}-9 \mathrm{H}-4,145-150$ & 79.95 & 882 & 820 & 384 & 10.52 & & 14.00 \\
\hline $115-707 \mathrm{~A}-12 \mathrm{H}-4,145-150$ & 108.75 & 928 & 633 & 369 & 34.29 & & 0.00 \\
\hline $115-707 \mathrm{~A}-15 \mathrm{H}-3,145-150$ & 136.05 & 953 & 751 & 342 & 15.07 & & 16.40 \\
\hline $115-707 \mathrm{~A}-20 \mathrm{X}-2,145-150$ & 178.15 & 1001 & 942 & 292 & 0.62 & 94.18 & 50.78 \\
\hline $115-707 C-3 R-5,145-150$ & 200.95 & 935 & 522 & 259 & 0.83 & 97. & 10.87 \\
\hline $115-707 \mathrm{~A}-25 \mathrm{X}-5,145-150$ & 207.15 & 1208 & 569 & 266 & 0.57 & & 63.64 \\
\hline $115-707 C-6 R-2,145-150$ & 225.45 & 1001 & 567 & 283 & 1.03 & 96.84 & 19.89 \\
\hline 115-707C-9R-2, 145-150 & 254.35 & 907 & 485 & 215 & 12.01 & 90.61 & 24.70 \\
\hline $115-707 C-15 R-1,145-150$ & 310.35 & 780 & 622 & 219 & 20.69 & 65.89 & 31.08 \\
\hline $115-708 \mathrm{~A}-1 \mathrm{H}-4,145-150$ & 5.95 & & 1124 & 467 & 1.06 & 94.05 & - \\
\hline $115-708 \mathrm{~A}-2 \mathrm{H}-4,145-150$ & 14.95 & 1737 & 1554 & 532 & 10.79 & 86.2 & 87.63 \\
\hline $115-708 \mathrm{~A}-3 \mathrm{H}-4,145-150$ & 24.55 & 1169 & 1152 & 676 & 4.28 & 91.67 & 22.49 \\
\hline $115-708 \mathrm{~A}-4 \mathrm{H}-4,145-150$ & 34.05 & 2105 & 3056 & 764 & 47.08 & 50.9 & 17.53 \\
\hline $115-708 \mathrm{~A}-5 \mathrm{H}-4,145-150$ & 43.55 & 982 & 1023 & 766 & 2.57 & 94.32 & 24.21 \\
\hline $115-708 \mathrm{~A}-6 \mathrm{H}-3,145-150$ & 51.65 & 1079 & 1023 & 759 & 25.31 & 73.18 & 17.60 \\
\hline $115-708 \mathrm{~A}-9 \mathrm{X}-1,145-150$ & 77.45 & 630 & 738 & 712 & 62.74 & 35.97 & 22.22 \\
\hline $115-708 \mathrm{~A}-12 \mathrm{X}-4,120-125$ & 107.10 & 828 & 874 & 708 & 1.24 & 97.01 & 17.48 \\
\hline $115-708 \mathrm{~A}-15 \mathrm{X}-4,120-125$ & 136.00 & 1374 & 1150 & 701 & 0.37 & 77.70 & 24.68 \\
\hline $115-708 \mathrm{~A}-18 \mathrm{X}-3,120-125$ & 162.00 & 1765 & 1357 & 697 & 1.10 & 97.49 & 38.33 \\
\hline $115-708 \mathrm{~A}-22 \mathrm{X}-4,145-150$ & 203.45 & 1245 & 1942 & 621 & 0.59 & $\bullet$ & 51.41 \\
\hline $115-708 \mathrm{~A}-24 \mathrm{X}-4,145-150$ & 222.75 & 483 & 1103 & 603 & 26.59 & 71.44 & 32.00 \\
\hline $115-709 \mathrm{~A}-1 \mathrm{H}-4,145-150$ & 5.95 & 1143 & 1242 & 342 & 6.16 & 91.73 & 10.32 \\
\hline $115-709 \mathrm{~A}-2 \mathrm{H}-4,145-150$ & 16.05 & 1080 & 1179 & 454 & 11.65 & 85.24 & 18.40 \\
\hline $115-709 \mathrm{~A}-3 \mathrm{H}-4,145-150$ & 25.65 & 1126 & 1546 & 549 & 8.71 & 92.27 & 33.33 \\
\hline $115-709 \mathrm{~A}-4 \mathrm{H}-3,145-150$ & 33.85 & 1113 & 1230 & 627 & 5.67 & 92.67 & 17.13 \\
\hline $115-709 \mathrm{~A}-6 \mathrm{H}-5,145-150$ & 54.65 & 949 & 1083 & 719 & 2.95 & 95.96 & 14.34 \\
\hline $115-709$ A-7H-5, 145- 150 & 64.25 & 1010 & 1032 & 753 & 3.94 & - & 8.40 \\
\hline $115-709 \mathrm{~A}-10 \mathrm{H}-5,120-125$ & 90.00 & 1090 & 1339 & 840 & - & - & 26.80 \\
\hline $115-709 \mathrm{~A}-13 \mathrm{H}-5,120-125$ & 123.40 & 1112 & 1036 & 835 & 3.68 & 64.12 & 6.43 \\
\hline $115-709 \mathrm{~A}-16 \mathrm{X}-5,120-125$ & 152.40 & 1025 & 1052 & 763 & 1.86 & 97.29 & 25.60 \\
\hline $115-709 \mathrm{~A}-19 \mathrm{H}-2,120-125$ & 177.20 & 1048 & 1114 & 836 & 1.93 & 96.91 & 11.20 \\
\hline $115-709$ B $-22 X-5,120-125$ & 204.00 & 1040 & 1289 & 816 & 2.17 & 93.29 & 17.60 \\
\hline $115-709 \mathrm{~B}-25 \mathrm{X}-4,145-150$ & 231.75 & 1390 & 1500 & 763 & 1.67 & 94.06 & 22.40 \\
\hline $115-709 C-28 X-2,145-150$ & 259.65 & 1038 & 1124 & 879 & 1.25 & 95.52 & 14.00 \\
\hline $115-709 \mathrm{C}-31 \mathrm{X}-4,145-150$ & 291.75 & 863 & 943 & 745 & 2.83 & 95.91 & 16.34 \\
\hline $115-709 \mathrm{C}-34 \mathrm{X}-4,145-150$ & 320.75 & 904 & 586 & 819 & 1.66 & 96.39 & 23.20 \\
\hline $115-709 C-37 X-4,145-150$ & 349.85 & 753 & 796 & 719 & 6.82 & 91.28 & 31.20 \\
\hline $115-710 \mathrm{~A}-1 \mathrm{H}-4,145-150$ & 5.95 & 1254 & 1344 & 323 & 11.09 & 80.52 & 18.65 \\
\hline $115-710 \mathrm{~A}-2 \mathrm{H}-4,145-150$ & 15.45 & 1278 & 1265 & 437 & 6.62 & 90.90 & 23.60 \\
\hline $115-710 \mathrm{~A}-3 \mathrm{H}-4,145-150$ & 22.15 & 1133 & 1450 & 494 & 1.93 & 95.13 & 24.40 \\
\hline $115-710 \mathrm{~A}-4 \mathrm{H}-4,145-150$ & 34.75 & 1104 & 1598 & 530 & 0.66 & 97.25 & 78.15 \\
\hline $115-710 \mathrm{~A}-6 \mathrm{H}-4,145-150$ & 53.85 & 1167 & 1472 & 530 & 0.60 & 99.05 & 87.00 \\
\hline $115-710 \mathrm{~A}-9 \mathrm{H}-5,120-125$ & 83.80 & 2303 & 2524 & 547 & 23.09 & 71.00 & 63.60 \\
\hline $115-710 \mathrm{~A}-12 \mathrm{H}-5,120-125$ & 112.70 & 2040 & 2430 & 504 & 0.22 & 96.53 & - \\
\hline $115-710 \mathrm{~A}-15 \mathrm{X}-3,115-125$ & 136.55 & 1142 & 1611 & 530 & 0.84 & 97.23 & 35.00 \\
\hline $115-710 \mathrm{~A}-18 \mathrm{X}-3,115-125$ & 165.55 & 1729 & 1602 & 525 & 1.03 & 97.54 & 26.40 \\
\hline $115-710 \mathrm{~A}-22 \mathrm{X}-3,115-125$ & 204.25 & 1636 & 1463 & 532 & 0.36 & 97.98 & 37.62 \\
\hline $115-711 \mathrm{~A}-1 \mathrm{H}-4,145-15 \mathrm{C}$ & 5.95 & 1368 & 684 & 274 & 1.56 & 94. & 73.31 \\
\hline $115-711 \mathrm{~A}-2 \mathrm{H}-3,145-150$ & 12.55 & 3663 & 628 & 282 & 7.03 & 87.72 & 63.20 \\
\hline $115-711 \mathrm{~A}-3 \mathrm{H}-4,145-150$ & 23.65 & 297 & 123 & 269 & 0.30 & 95.19 & - \\
\hline $115-711 \mathrm{~A}-4 \mathrm{H}-5,145-150$ & 34.75 & 1740 & 1005 & 275 & 0.79 & 94.87 & - \\
\hline $115-711 \mathrm{~A}-5 \mathrm{H}-5,145-150$ & 44.35 & - & - & 273 & 0.07 & 91.52 & - \\
\hline $115-711 \mathrm{~A}-6 \mathrm{H}-5,115-120$ & 53.75 & - & - & 287 & 0.12 & 97.90 & - \\
\hline $115-711 \mathrm{~A}-9 \mathrm{H}-5,115-120$ & 82.75 & 1596 & 1359 & 302 & 0.61 & 97.70 & 4.44 \\
\hline $115-711 \mathrm{~A}-12 \mathrm{X}-2,115-120$ & 107.15 & 2451 & 1437 & 312 & 0.51 & 75.05 & 86.15 \\
\hline $115-711 \mathrm{~A}-15 \mathrm{X}-5,115-120$ & 140.75 & 1498 & 1492 & 284 & 0.33 & 97.72 & 52.22 \\
\hline $115-711 \mathrm{~A}-18 \mathrm{X}-3,140-150$ & 167.10 & 1413 & 1369 & 288 & 0.56 & 98.42 & 57.27 \\
\hline
\end{tabular}


Table 3 (continued).

\begin{tabular}{|c|c|c|c|c|c|c|c|}
\hline \multirow[t]{2}{*}{$\begin{array}{l}\text { Core, sample, } \\
\text { interval }(\mathrm{cm})\end{array}$} & \multirow[t]{2}{*}{$\begin{array}{l}\text { Depth } \\
\text { (mbsf) }\end{array}$} & \multicolumn{3}{|c|}{$\begin{array}{l}\text { Sr concentration } \\
\text { solid (ppm) }\end{array}$} & \multicolumn{3}{|c|}{ Percentage of sediment } \\
\hline & & $>62$ & $<62$ & Equil. & $>62$ & $<62$ & Insoluble \\
\hline $115-711 \mathrm{~A}-21 \mathrm{X}-4,140-150$ & 197.60 & 1507 & 938 & 321 & 1.48 & 97.15 & 29.20 \\
\hline $115-711 \mathrm{~A}-24 \mathrm{X}-3,140-150$ & 225.10 & 1297 & 980 & 320 & 31.06 & 64.61 & 35.60 \\
\hline $115-712$ A-1R-5, $145-150$ & 7.45 & 877 & 988 & 264 & 8.84 & 89.34 & 17.60 \\
\hline $115-712 \mathrm{~A}-2 \mathrm{R}-2,15-150$ & 15.48 & 932 & 1019 & 274 & 9.61 & 87.23 & 10.84 \\
\hline $115-712 A-3 R-2,140-150$ & 23.40 & 871 & 1118 & 288 & 10.19 & 85.78 & 16.73 \\
\hline $115-712 \mathrm{~A}-4 \mathrm{R}-2,140-150$ & 31.50 & 1047 & 818 & 304 & 7.30 & 88.55 & 11.20 \\
\hline $115-712 \mathrm{~A}-6 \mathrm{R}-2,140-150$ & 50.80 & 755 & 697 & & 23.19 & 74.23 & 0.00 \\
\hline $115-713 A-2 R-4,145-150$ & 7.55 & 1031 & 1046 & 295 & 12.95 & 84.73 & 25.79 \\
\hline $115-713 \mathrm{~A}-3 \mathrm{R}-4,145-150$ & 17.15 & 962 & 1065 & 302 & 10.40 & 85.71 & 19.20 \\
\hline $115-713 A-4 R-4,145-150$ & 26.75 & 1075 & 1077 & 307 & 11.20 & 83.02 & 15.94 \\
\hline $115-713 A-5 R-2,145-150$ & 33.45 & 826 & 545 & 309 & 7.55 & 90.01 & 36.40 \\
\hline $115-713 \mathrm{~A}-6 \mathrm{R}-2,145-150$ & 43.05 & 1089 & 670 & 301 & 1.35 & 95.60 & 60.59 \\
\hline $115-713 \mathrm{~A}-9 \mathrm{R}-1,145-150$ & 70.55 & 974 & 597 & 280 & 3.00 & 96.03 & 25.90 \\
\hline $115-713 \mathrm{~A}-12 \mathrm{R}-1,147-150$ & 99.57 & 1133 & 396 & 269 & 6.78 & 88.23 & 27.60 \\
\hline $115-713 \mathrm{~A}-17 \mathrm{R}-3,150-155$ & 150.22 & - & 78 & 182 & 47.37 & 48.07 & - \\
\hline $115-714 \mathrm{~A}-1 \mathrm{H}-1,145-150$ & 1.45 & 1564 & 1417 & 283 & 20.73 & 77.85 & 32.00 \\
\hline $115-714 \mathrm{~A}-2 \mathrm{H}-4,145-150$ & 8.75 & 2000 & 2484 & 385 & 12.24 & 85.41 & 25.00 \\
\hline $115-714 \mathrm{~A}-3 \mathrm{H}-4,145-150$ & 18.35 & 1211 & 1328 & 461 & 23.63 & 89.47 & 15.14 \\
\hline $115-714 \mathrm{~A}-4 \mathrm{H}-5,145-150$ & 28.08 & 1074 & 1677 & 442 & 17.04 & 81.02 & 43.20 \\
\hline $115-714 \mathrm{~A}-5 \mathrm{H}-5,145-150$ & 35.15 & 971 & 1087 & 480 & 16.84 & 80.09 & 20.72 \\
\hline $115-714 \mathrm{~A}-6 \mathrm{H}-4,145-150$ & 47.35 & 1412 & 1548 & 450 & 19.53 & 61.90 & 36.65 \\
\hline $115-714 \mathrm{~A}-9 \mathrm{H}-2,145-150$ & 73.15 & 1228 & 1307 & 487 & 20.90 & 19.71 & 23.60 \\
\hline $115-714 \mathrm{~A}-12 \mathrm{H}-4,120-125$ & 104.58 & 1176 & 1042 & 507 & 11.25 & 90.52 & 15.54 \\
\hline $115-714 \mathrm{~A}-15 \mathrm{X}-4,120-125$ & 131.07 & 1194 & 1002 & 555 & 14.53 & 80.29 & 18.25 \\
\hline $115-714 \mathrm{~A}-18 \mathrm{X}-4,120-125$ & 161.40 & 979 & 843 & 517 & 15.06 & 81.12 & 16.27 \\
\hline $115-714 \mathrm{~A}-22 \mathrm{X}-4,120-125$ & 200.10 & 1291 & 1086 & 460 & 21.24 & 73.75 & 13.94 \\
\hline $115-714 \mathrm{~A}-25 \mathrm{X}-1,145-150$ & 224.75 & 1266 & 916 & 388 & 31.62 & 63.24 & 9.16 \\
\hline $115-715 \mathrm{~A}-1 \mathrm{R}-3,145-150$ & 4.45 & 1622 & 2404 & 268 & 17.98 & 81.40 & 62.30 \\
\hline $115-715 \mathrm{~A}-2 \mathrm{R}-4,145-150$ & 14.05 & 987 & 2144 & 291 & 7.03 & 92.52 & 34.92 \\
\hline $115-715 \mathrm{~A}-3 \mathrm{R}-4,145-150$ & 23.75 & 1871 & 2622 & 310 & 10.69 & 87.58 & 65.34 \\
\hline $115-715 A-4 R-4,145-150$ & 33.45 & 1522 & 2177 & 338 & 8.22 & 87.76 & 46.80 \\
\hline $115-715 \mathrm{~A}-5 \mathrm{R}-4,145-150$ & 43.05 & 1730 & 2839 & 343 & 11.77 & 83.83 & 71.71 \\
\hline $115-715 \mathrm{~A}-6 \mathrm{R}-4,145-150$ & 52.75 & 1087 & - & 337 & 21.84 & 76.53 & 35.46 \\
\hline $115-715 \mathrm{~A}-9 \mathrm{R}-4,145-150$ & 81.65 & 1263 & 922 & 314 & 13.50 & 81.27 & 25.60 \\
\hline $115-716 \mathrm{~A}-1 \mathrm{H}-3,145-150$ & 4.45 & 2611 & 4056 & 273 & 24.25 & 57.21 & 52.78 \\
\hline $115-716 \mathrm{~A}-2 \mathrm{H}-4,145-150$ & 12.85 & 2892 & 4643 & 309 & 30.69 & 66.79 & 59.60 \\
\hline $115-716 \mathrm{~A}-3 \mathrm{H}-4,120-125$ & 22.20 & 2316 & 2551 & 323 & 23.74 & 74.37 & 9.92 \\
\hline $115-716 \mathrm{~A}-4 \mathrm{H}-4,145-150$ & 32.05 & 2762 & 2439 & 353 & 50.09 & 48.22 & 21.12 \\
\hline $115-716 \mathrm{~A}-5 \mathrm{H}-4,145-150$ & 41.75 & 2081 & 4362 & 402 & 18.77 & 79.09 & 35.06 \\
\hline $115-716 \mathrm{~A}-6 \mathrm{H}-4,120-125$ & 51.20 & 1975 & 3637 & 390 & 28.13 & 68.91 & 41.04 \\
\hline $115-716 \mathrm{~A}-9 \mathrm{H}-4,120-125$ & 80.00 & 2793 & 2115 & 451 & 26.86 & 91.49 & 49.80 \\
\hline $115-716 \mathrm{~A}-12 \mathrm{H}-4,120-125$ & 108.90 & 1018 & 1198 & 840 & 29.94 & 68.34 & 0.00 \\
\hline $115-716 \mathrm{~A}-15 \mathrm{H}-4,120-125$ & 137.80 & 2020 & 1861 & 935 & 28.37 & 69.64 & 29.37 \\
\hline $115-716 \mathrm{~A}-18 \mathrm{H}-4,115-125$ & 166.65 & 1087 & 1487 & 929 & 31.46 & 66.99 & 39.29 \\
\hline $115-716 \mathrm{~A}-21 \mathrm{H}-4,115-125$ & 195.75 & 2427 & 1191 & 919 & 10.42 & 86.99 & 10.04 \\
\hline $115-716 \mathrm{~A}-24 \mathrm{H}-4,140-150$ & 225.10 & 1639 & 2034 & 928 & 17.73 & 78.12 & 22.00 \\
\hline $115-716 \mathrm{~A}-27 \mathrm{H}-4,140-150$ & 254.00 & 2540 & 1429 & 855 & 4.81 & 93.46 & 18.80 \\
\hline
\end{tabular}

Note: The equilibrium refers to the calculated concentration of $\mathrm{Sr}$ in calcite precipitated in equilibrium with the present-day pore fluids. Dash $(-)$ indicates that no analyses were performed; asterisk (*) denotes that recovery was greater than $100 \%$.

gated. When normalized to surface seawater chloride ratios using the following equation, the absolute changes in excess alkalinity (A) can be established. Similar calculations can be made for $\mathrm{SO}_{4}^{2-}$. The results of these calculation are shown in Figures $8 \mathrm{~A}$ and $8 \mathrm{~B}$.

$$
\begin{aligned}
\text { Excess }(\mathrm{A})= & {[\mathrm{A}(\text { sample }) / \mathrm{Cl}(\text { sample })] } \\
& -[\mathrm{A}(\text { seawater }) /(\mathrm{Cl}(\text { seawater })] \\
& \cdot \mathrm{Cl}(\text { sample }) .
\end{aligned}
$$

Using the reaction in Equation 2, it can be calculated that for every mole of $\mathrm{SO}_{4}^{2-}$ used during the oxidation of organic materials, two moles of carbonate alkalinity are created. Therefore, in the absence of the precipitation or dissolution of calcium carbonate, the alkalinity should increase at twice the rate at which sulfate is removed. Similar calculations can be carried out using phosphate and ammonia at those sites for which data are reported. The use of such a strict stoichiometry has been suggested to be not completely valid, as the differential diffusion coefficients of $\mathrm{O}_{2}, \mathrm{HCO}_{3}^{-}$, and $\mathrm{SO}_{4}^{2-}$ act to change concentrations of these species with time (Emerson et al., 1982).

As an example of the magnitude of change that might be expected from the diffusion of sulfate and alkalinity, let us consider a difference in sulfate concentration of $8 \mathrm{mM}$, corresponding to a change of alkalinity of $16 \mathrm{mM}$. Using a standard diffusion equation and the diffusion coefficients for $\mathrm{HCO}_{3}^{-}$and $\mathrm{SO}_{4}^{2-}$ given by $\mathrm{Li}$ and Gregory (1974) $\left(11.8 \mathrm{vs} .10 .7 \times 10^{-6} \mathrm{~cm} /\right.$ sec at $25^{\circ} \mathrm{C}$ ), the magnitude of the changes in the concentration of these species as a result of diffusion and the resultant alkalinity anomaly can be estimated for different periods of time. These calculations are shown in Figure 9.

As may be observed, within $1 \mathrm{~m}$.y. the original sulfate and alkalinity gradients have almost disappeared. As most of the sediments are older than $1 \mathrm{~m} . \mathrm{y}$. , and the sulfate and alkalinity 

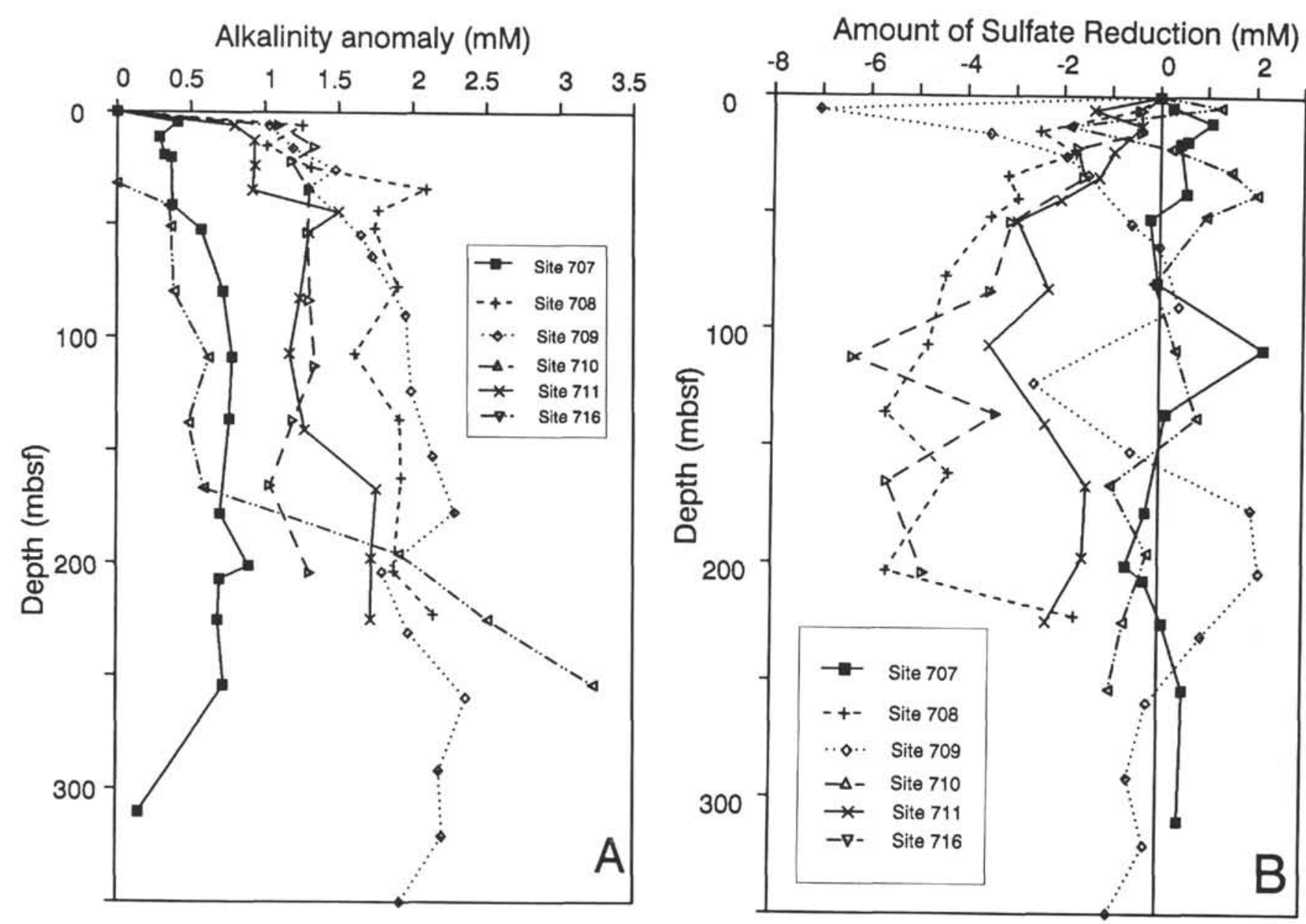

Figure 8. Excess alkalinity (A) and excess $\mathrm{SO}_{4}^{2-}$ (B) for the "carbonate" sites and Site 716.

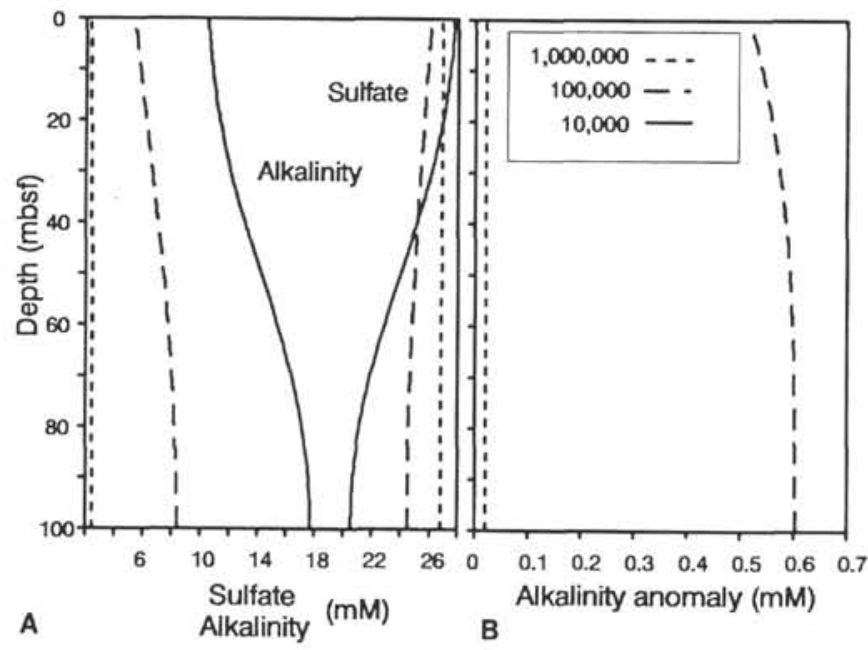

Figure 9. Results of the changes in the concentration (c) of sulfate and alkalinity (A) as a result of diffusion $\left(\partial c / \partial t=D_{b} \partial^{2} c / \partial x^{2}\right)$ for different times of diffusion $(t)$ and depths $(x)$. The diffusion coefficient $D_{b}$ for sulfate and alkalinity is taken from Li and Gregory (1974). Calculations assume an initial section of sediment $50 \mathrm{~m}$ thick with a concentration of $20 \mathrm{mM} \mathrm{SO}_{4}^{2-}$ and $16 \mathrm{mM}$ alkalinity. Further reactions involving these components is then stopped, and diffusion along the concentration gradients takes place. The alkalinity anomaly produced as a result of diffusion is shown in (B). gradients are considerably less than those used in this example, we feel that diffusion along concentration gradients cannot be responsible for the deficit of alkalinity observed at the Leg 115 sites. In fact, as the diffusion coefficient of $\mathrm{O}_{2}$ is approximately 2 times that of $\mathrm{HCO}_{3}^{-}$, there should be an excess of alkalinity production relative to sulfate reduction, particularly in the upper portion of the profile, whereas there is less alkalinity than expected. Other reactions involving either sulfate or alkalinity such as methanogenesis or precipitation of celestite can be ruled out as there is no evidence of any methane production in these sediments (Backman, Duncan, et al., 1988), and, with the exception of Site 716 , all sediments are undersaturated with respect to celestite.

The calculations using Equation 3 for sulfate suggest that some sites, notably those with the highest calculated rates of recrystallization, show $\mathrm{SO}_{4}^{2-}$ reduction in excess of what is visible in the alkalinity measured in these pore waters. For example, at Site 709 there is a reduction of approximately $7 \mathrm{mM}$ of $\mathrm{SO}_{4}^{2-}$ at 5.95 mbsf. The alkalinity, however, increases only by approximately $1 \mathrm{mM}$. In order to account for this loss in alkalinity, calcium carbonate must be precipitated and $\mathrm{Ca}^{2+}$ lost from solution. Such precipitation is not visible in the calcium concentration, which actually increases over the same interval. Apparently, either substantial amounts of $\mathrm{Ca}^{2+}$ have been diffused or advected into the sediment and have been removed as calcium carbonate, or sulfate is involved in the precipitation of some other mineral phase and the decrease observed is not totally a result of the oxidation of organic material. However, if the sulfate de- 
creases represent the true increase in alkalinity, alkalinity must be lost from the pore waters in the form of the precipitation of calcium carbonate. The problem with this notion is that, in order to account for $14 \mathrm{mM}$ of alkalinity, the $\mathrm{Ca}^{2+}$ concentration must decrease by $50 \%$ of this amount, or $7 \mathrm{mM}$.

Such a loss of alkalinity and calcium could occur in two places, either within the sediments themselves or during the retrieval and degassing of the cores. Some evidence for this later hypothesis is provided by comparison of samples taken with the Barnes in-situ water sampler and waters squeezed from similar intervals (Table 2). The in-situ samples, which were retrieved and analyzed with only minimal pressure loss compared to the normal squeezed samples, contained approximately $1 \mathrm{mM}$ more $\mathrm{Ca}^{2+}$ and alkalinity than water from the squeezed intervals at comparable depths. Whereas this change is still insufficient to make up for the apparent depletion in sulfate, it is possible that significantly greater amounts of calcite could have precipitated in the time taken to retrieve the sample from the chamber of the Barnes water sampler and perform the analyses. If the loss in the calcium and alkalinity takes place during retrieval, the interstitial calcium concentrations can be corrected for the calcium lost during this precipitation.

The results of these calculations are shown in Figure 10. Note that this calculation assumes that for every mole of $\mathrm{Ca}^{2+}$ precipitated, two moles of alkalinity are lost. From these data it can be seen that in the two shallowest Sites 707 and 716, the excess $\mathrm{Ca}^{2+}$ and corrected $\mathrm{Ca}^{2+}$ profiles are in good agreement with measured concentrations, considering the errors and assumptions involved in the calculations. Hence the loss of $\mathrm{Ca}^{2+}$ and alkalinity during retrieval from shallow-water depths is not as severe as from the deeper sites and may therefore support the notion that the loss in alkalinity and calcium is a depth-related effect, the largest discrepancies occurring at samples retrieved from the deepest water depths.

In Sites 708,710 , and 711 , the $\mathrm{Ca}^{2+}$ profile is changed from a profile which is seemingly diffusively controlled to one in which there appears to be water movement out of the sediments (Fig. 10). That is to say the gradient is the steepest nearest the surface. At Site 709 , the corrected $\mathrm{Ca}^{2+}$ profile does not show any consistent trend with depth, and in fact rises very sharply near the sediment-water interface, decreasing rapidly with increasing depth sub-bottom. While we do not have any definitive explanation for this trend, the observed gradients at Site 709 could be consistent with horizontal convection of fluid through the sediments.

Other anomalies have been reported in the sediments from Site 709. For example in a study of the magnetic properties of the sediments from Leg 115, Robinson (this volume) noted that the magnetic signal had been largely removed between 20 and 120 mbsf. This, he concluded, was a result of conversion of magnetite to pyrite under suboxic conditions in the presence of abundant organic material. While the pore-water and bulk-sediment geochemistry do not support this idea, we cannot help but notice the apparent similarity in the distribution of the anomalous magnetic susceptibility (Robinson, this volume; Fig. 23) with the unusual $\mathrm{Ca}^{2+}$ concentrations. Perhaps horizontal advection of normal seawater would enhance the removal of magnetic minerals and eliminate the $\mathrm{Ca}^{2+}$ gradients.

Finally, it may be important that the same phenomenon of excess sulfate depletion is evident in data collected from DSDP

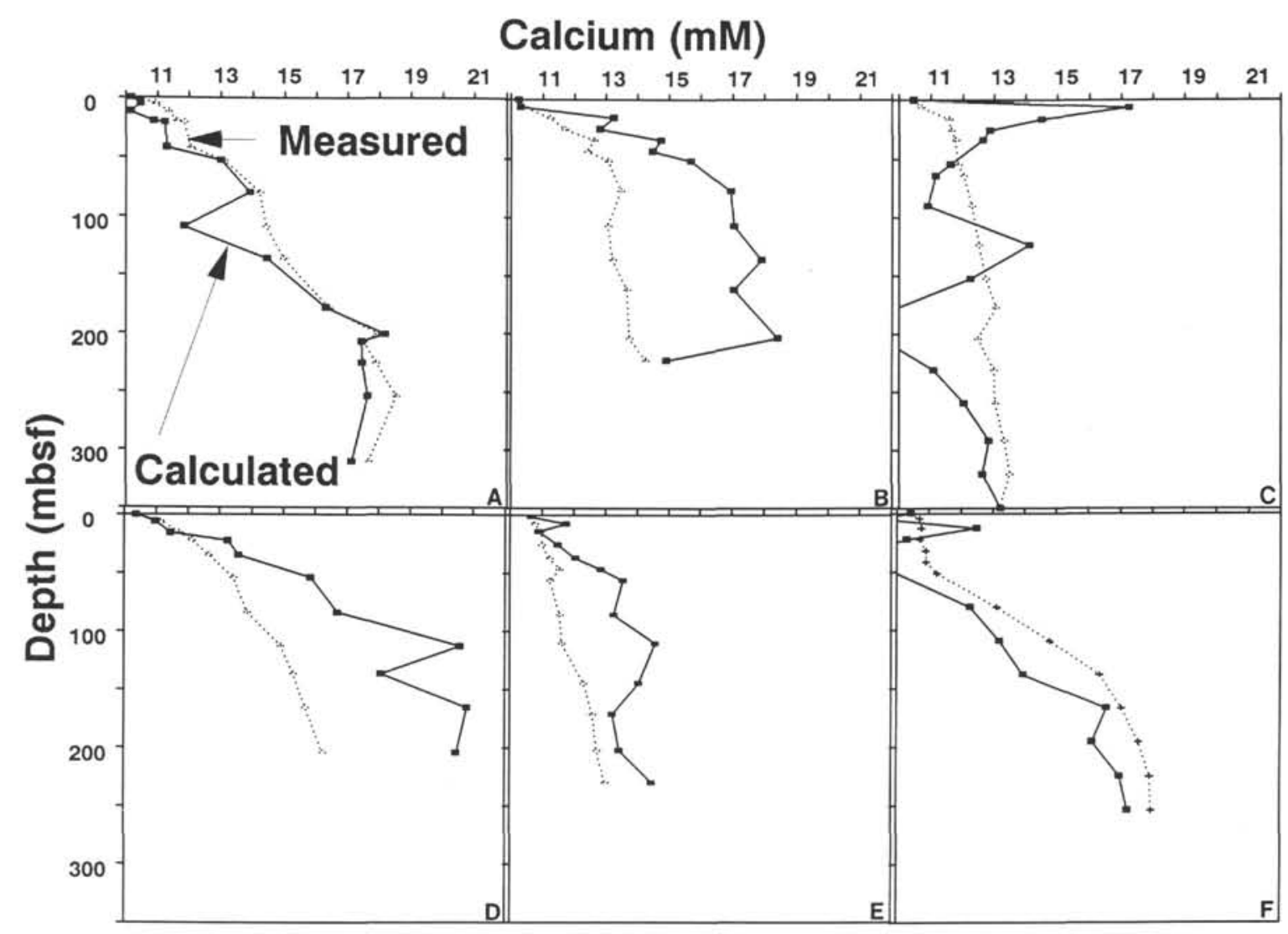

Figure 10. Measured $\mathrm{Ca}^{2+}$ and "corrected" $\mathrm{Ca}^{2+}$ profiles for Sites 707 (A), 708 (B), 709 (C), 710 (D), 711 (E); and 716 (F). Note the change in the shape of the profile in Sites 708, 710, and 711, the absence of significant changes in Sites 707 and 716 , and the irregular pattern in Site 709. 
and ODP sites. For example, in the studies of Baker (1986) in which the profiles of trace elements were largely considered to be diffusively controlled, significant $\mathrm{Ca}^{2+}$ deficiencies also exist. Whether such discrepancies are sampling artifacts or are in fact real, the flux and $\mathrm{Ca}^{2+}$ gradients in oceanic carbonate sediments need to be reexamined.

Some support for the notion that the observed sulfate changes are artifacts is provided by comparison of the change in the concentrations of ammonia at Site 709. Increase in ammonia is considerably lower than that suggested by Redfield stoichiometry. They are, however, much more in agreement with increases in alkalinity. It is possible, based on the evidence, that depletion in $\mathrm{SO}_{4}^{2-}$ is not entirely a result of oxidation of organic material, but may be a consequence of the participation of $\mathrm{SO}_{4}^{2-}$ in some other system, or perhaps is a result of its adsorption by clay minerals.

\section{Solids}

A further method used to estimate recrystallization involves the comparison of $\mathrm{Sr}$ content of the sediment with the equilibrium $\mathrm{Sr}$ concentration predicted from the pore-water chemistry (Baker et al., 1982). The depth at which the predicted equilibrium values coincide with the actual values theoretically is the depth of $100 \%$ recrystallization. This calculation is shown graphically for Sites 707-711 and Site 716 in Figures $6 \mathrm{~A}$ to $6 \mathrm{~F}$, and can be expressed by the following equation:

$$
\% \text { recrystallization }=\frac{\left(\mathrm{Sr}^{2+} / \mathrm{Ca}^{2+}\right)_{\text {initial }}-\left(\mathrm{Sr}^{2+} / \mathrm{Ca}^{2+}\right)_{\text {observed }}}{\left(\mathrm{Sr}^{2+} / \mathrm{Ca}^{2+}\right)_{\text {initial }}-\left(\mathrm{Sr}^{2+} / \mathrm{Ca}^{2+}\right)_{\text {equilibrium }}} \text {. }
$$

This method has not proven useful for estimating recrystallization in Leg 115 carbonates for several reasons. First, Baker et al. (1982) stated that the equation was useful only if the $\mathrm{Sr}^{2+}$ / $\mathrm{Ca}^{2+}$ ratio of the fluids did not vary through time. Such is obviously not the case for our samples. Second, the calculation assumes that the initial $\mathrm{Sr}^{2+} / \mathrm{Ca}^{2+}$ ratio of the solids has been constant through time and is necessarily very sensitive to the value chosen. At many Leg 115 sites, the $\mathrm{Sr}^{2+} / \mathrm{Ca}^{2+}$ ratio has apparently varied through time and in some instances actually increases with depth (i.e., Site 708). Third, small amounts of true recrystallization can result in apparently large $\% \mathrm{R}$ values using this method because of its sensitivity to the $\mathrm{Sr}^{2+} / \mathrm{Ca}^{2+} \mathrm{ra}-$ tio of the pore fluid. For example, if it is assumed that $2 \%$ of a sediment with an initial $\mathrm{Sr}^{2+}$ content of $1500 \mathrm{ppm}$ becomes recrystallized with a content of $750 \mathrm{ppm} \mathrm{Sr}$, and all the excess $\mathrm{Sr}^{2+}$ goes into the pore fluids, then the $\mathrm{Sr}^{2+} / \mathrm{Ca}^{2+}$ of carbonates precipitated in equilibrium should change by a factor of 5 . According to the equation proposed by Baker et al. (1982), the calculated recrystallization is $60 \%$. In essence, the formula assumes that the pore fluid $\mathrm{Sr}^{2+} / \mathrm{Ca}^{2+}$ ratio controls the same ratio in the solid, when in fact the $\mathrm{Sr}^{2+} / \mathrm{Ca}^{2+}$ ratio of the fluids is controlled by the small amount of carbonate which is recrystallized at any one time.

Although much better estimates of recrystallization can be obtained by examining the total loss of $\mathrm{Sr}^{2+}$ from the system, the graphical presentation provides a qualitative estimate of visualizing recrystallization. For example, at Site 707 (Figure 6A), the site with the lowest estimated rate of recrystallization, the calculated equilibrium $\mathrm{Sr}$ concentration remains below that of the measured concentrations of the fine and coarse fractions throughout the core, showing no convergence. In contrast, at Site 709 (Figure 6C), the sediment and the equilibrium concentration are in approximate agreement in the sediments at the bottom of the hole, where we estimate recrystallization to be as much as $50 \%$.

\section{Calcium and Magnesium}

A significant finding of previous work on pore waters obtained from DSDP sites is that positive $\mathrm{Ca}^{2+}$ and negative $\mathrm{Mg}^{2+}$ gradients with increasing depth sub-bottom in the interstitial pore fluids can be related to the alteration of underlying crustal rocks (Lawrence et al., 1975). Such fluxes can be compared using a diffusion-sedimentation-compaction model as given by the following equation:

$$
\partial C(z, T) / \partial T=D_{b} \partial^{2} C / \partial Z^{2}+v \partial C / \partial Z+\Sigma J .
$$

In this equation, $C=$ the concentration of either the species under consideration as a function of depth $(z)$ and time $(T) ; \Sigma J$ $=$ sum of production or consumption terms involving the relevant elements; $v=$ the sedimentation rate; and $D_{b}=$ solute diffusion coefficient.

If $\mathrm{Ca}^{2+}$ and $\mathrm{Mg}^{2+}$ are controlled principally by this equation, and there are no chemical reactions involving these elements occurring in the sediments, then $J=0$ and the behavior of $\mathrm{Ca}^{2+}$ and $\mathrm{Mg}^{2+}$ can be considered to be conservative and their concentrations linearly correlated. Based on such an assumption, McDuff (1981) classified data from DSDP Legs 1 through 53 into sites (1) without gradients; (2) with gradients but no linear correlations; and (3) with gradients and linear correlations. Although conservative behavior for $\mathrm{Ca}^{2+}$ and $\mathrm{Mg}^{2+}$ is implied if there is a linear correlation between these elements, McDuff (1981) provided no criteria to assess whether a correlation actually exists. It is assumed in this paper that a conservative relationship exists if there is a statistically significant correlation between $\mathrm{Ca}^{2+}$ and $\mathrm{Mg}^{2+}$.

The magnitude of the $\mathrm{Ca}^{2+} / \mathrm{Mg}^{2+}$ gradient has been suggested to be a result of nature of the underlying basement rocks. For example, Baker (1986) proposed that more positive $\mathrm{Ca}^{2+}$ / $\mathrm{Mg}^{2+}$ gradients $(>-0.6)$ were representative of felsic basement rocks. In support of this contention, he noted that $\mathrm{Ca}^{2+} / \mathrm{Mg}^{2+}$ gradients from three groups of sites (Sites 346 and 349 on the Jan-Mayen ridge; Site 116 of the Rockall bank; and Site 237 on the Mascarene Ridge) all possessed $\mathrm{Ca}^{2+} / \mathrm{Mg}^{2+}$ gradients between -0.6 and -0.4 and were all presumed to be underlain by felsic basement. On the basis of this comparison, Baker concluded that Sites $588,590,591$, and 592 on the Lord Howe Rise were also resting on felsic basement. However, in none of these sites were felsic materials actually drilled.

In addition, as discussed previously, alkalinities at the Lord Howe Rise sites were not as high as might be expected from sulfate reduction, suggesting that calcium and alkalinity concentrations of the pore waters have been significantly altered during retrieval or through carbonate reactions in the sediments. Loss of $\mathrm{Ca}^{2+}$ by this process would substantially reduce the measured $\mathrm{Ca} / \mathrm{Mg}$ ratio. For example, Table 4 shows the gradients for the Leg 115 sites calculated before and after making a correction for $\mathrm{Ca}^{2+}$ loss. At all sites other than 709 , the $\mathrm{Ca} / \mathrm{Mg}$ ratio becomes substantially more negative and closer to values proposed as a result of basaltic alteration.

Of particular relevance to the Leg 115 studies are the observations on pore water from Site 237, drilled close to Site 707 on the northern Mascarene Plateau (Fig. 1). Although both Sites 237 and 707 penetrated similar types of sediments, were drilled in similar water depths (Site 237 was drilled in $1623 \mathrm{~m}$ water depth), and were geographically very close, their $\mathrm{Ca} / \mathrm{Mg}$ gradients were significantly different (Site $707=-0.82$; Site $237=$ - 0.57; Sandstrom and Gieskes, 1974). Other "carbonate" sites such as Sites 708 and 709 have $\mathrm{Ca} / \mathrm{Mg}$ gradients similar to Site 237 , but are situated farther away from the Seychelles bank. Site 
Table 4. The $\mathrm{Ca} / \mathrm{Mg}$ gradients measured from the "carbonate" sites before and after correction for $\mathrm{Ca}^{2+}$ loss as discussed in the text.

\begin{tabular}{lccccc}
\hline & $\mathrm{Ca} / \mathrm{Mg}$ & \multicolumn{5}{c}{$\mathrm{Ca} / \mathrm{Mg}$} & $\mathrm{r}$ & $\mathrm{n}$ \\
Site & 1 & $\mathrm{r}$ & 2 & & \\
\hline 707 & $-0.82(0.03)$ & 0.94 & $-0.87(0.06)$ & 0.98 & 15 \\
708 & $-0.54(0.07)$ & 0.82 & $-1.29(0.18)$ & 0.85 & 11 \\
709 & $-0.55(0.02)$ & 0.97 & $+0.66(0.32)$ & 0.23 & 16 \\
710 & $-1.01(0.09)$ & 0.93 & $-2.00(0.24)$ & 0.90 & 10 \\
711 & $-0.82(0.17)$ & 0.68 & $-0.38(0.44)$ & 0.50 & 12 \\
716 & $-0.83(0.05)$ & 0.95 & $-0.81(0.05)$ & 0.96 & 13 \\
236 & -1.70 & & & & \\
237 & -0.57 & & & & \\
239 & -1.85 & & & & \\
245 & -1.00 & & & & \\
\hline
\end{tabular}

Note: $\mathrm{Ca} / \mathrm{Mg}$ gradients are given for Sites 236, 237, 239, and 245 (see Fig. 1 for locations; data from Sandstrom and Gieskes, 1974; Gieskes, 1974).

710 , situated close to Site 709 on the Madingley Rise, has a gradient similar to Site 711. Site 237, as noted previously, has been used by various authors (McDuff, 1981; Baker, 1986) as an example of a site which might be underlain by felsic basement; however, by virtue of the positions of Site 707 and the other "carbonate" sites relative to Site 237 and the Seychelles bank (Fig. 1), where granitic rocks are found exposed on the surface, the $\mathrm{Ca} / \mathrm{Mg}$ gradient at Site 237 cannot be used to support a granitic basement at Site 237.

Based the apparent random distribution of the $\mathrm{Ca} / \mathrm{Mg}$ gradients of the Leg 115 sites and the sites drilled during DSDP Legs 24 and 25 , we conclude that previous assessments regarding the magnitude of the $\mathrm{Ca} / \mathrm{Mg}$ gradient in relation to the nature of the basement rocks, at least in the Indian Ocean, are probably incorrect. For example, the wide range of $\mathrm{Ca} / \mathrm{Mg}$ gradients measured in this study ( -0.54 to -1.01$)$ and from nearby Sites 236 , $237,238,239$, and $245(-0.57$ to -1.85$)$ (Table 4$)$ would lead to the conclusion that a wide variety of basement rock types were present in this area, whereas in fact all the basement rocks are probably basalts.

The precise reasons for the wide variation in $\mathrm{Ca} / \mathrm{Mg}$ gradients are probably at least partially related to the observation of $\mathrm{Ca}^{2+}$ loss during the retrieval of the core and the presence of significant carbonate reactions in the sediment which do not alter the apparent conservative relationship between $\mathrm{Ca}^{2+}$ and $\mathrm{Mg}^{2+}$. Additional constraints may be placed by the actual $\mathrm{Ca} /$ $\mathrm{Mg}$ ratio of the basalts and the rate of hydrolysis of the aluminosilicates. As proposed by McDuff (1981), at low rates of hydrolysis, $\mathrm{Mg}^{2+}$ uptake exceeds $\mathrm{Ca}^{2+}$ release, the proportion being controlled by the ratio of alkalinity supplied by the dissolution of calcic aluminosilicates to that supplied by sodic aluminosilicates. Hence, low rates of basalt alteration would produce $\mathrm{Ca} / \mathrm{Mg}$ gradients close to unity when compared to basalts altered at higher rates.

\section{Interpretation of Pore-water Si Profiles}

Concentrations of Si are typically extremely low in the surface oceans as a result of the incorporation of $\mathrm{Si}$ in skeletons of siliceous microorganisms living in the photic zone. In fact, in this study, concentrations of $\mathrm{Si}$ were below detection levels (1 $\mu \mathrm{M}$ ), lower than the $2 \mu \mathrm{M}$ values reported by Weiss et al. (1983) for surface Indian Ocean waters. As radiolarians and diatoms die and sink to the bottom, their siliceous valves dissolve, resulting in an increase in Si concentration in the deeper water. Typical bottom-water Si concentrations at $1522 \mathrm{~m}$ are approximately $100 \mu \mathrm{M}$, increasing to $127 \mu \mathrm{M}$ at $4487 \mathrm{~m}$ water depth (data from Station 424 of the GEOSECS expedition; Weiss et al., 1983).
In contrast to these bottom-water concentrations, pore water from the first squeezed section of each core showed a large increase in the concentrations of $\mathrm{Si}$, ranging from $711 \mu \mathrm{M}$ at Site 711 to $449 \mu \mathrm{M}$ at Site 712 , reflecting the dissolution of siliceous tests in a semi-closed system. An exception to this occurs at Site 707 , where $\mathrm{Si}$ concentrations in the pore fluids are initially as low as $266 \mu \mathrm{M}$. This low concentration corresponds to an absence of radiolarians and diatoms in the sediments and is a consequence of the location of this site at the southern limit of the present equatorial belt of silica production.

Increases in the pore fluid concentration of $\mathrm{Si}$ at $\mathrm{Site} 707$ and other sites during the Pliocene and late Miocene result from the continued dissolution of siliceous fossils and is limited by the saturation of authigenic silica minerals opal-CT and quartz (Kastner, 1979); Site 707 was located in the silica-producing belt during this period (Mikkelsen, this volume). During the early and middle Miocene, the absence of siliceous components in the sedimentary record correlates with a decrease in the interstitial pore-water $\mathrm{Si}$ concentrations at all sites. The extent of this depletion cannot be fully appreciated as a result of the small numbers of samples taken in this time interval.

To constrain the extent of diagenetic reactions involving $\mathrm{Si}$ that occur in the sediments, the Si profiles that might be produced as a result of diffusion only can be calculated using a simple diagenetic equation previously described (Equation 5).

If Site 707 is used as an example and it is assumed that the $\mathrm{Si}$ concentration of the interstitial waters was approximately 700 $\mu \mathrm{M}$ for a period of $20 \mathrm{~m}$.y. (corresponding to an interval of 150 $\mathrm{m}$ ), and then became $100 \mu \mathrm{M}$ (approximate modern bottom-water Si concentrations) for an interval of $30 \mathrm{~m}$.y. up to the present day with no further reactions involving either the dissolution or precipitation of silica $(J=0)$, then the results of this equation predict that the original $\mathrm{Si}$ concentration gradient should not be visible at the present time. In fact, there should be only a minimal difference in the $\mathrm{Si}$ concentrations between sediments older than $20 \mathrm{Ma}$ and those younger, less than that currently observed. Slight changes in the bulk diffusion coefficient will not appreciably change this calculation. Therefore, to maintain the lower Si concentrations in the portions of the core that do not contain siliceous microfossils, there must be consumption of $\mathrm{Si}$ in these areas. Similarly, there must be continued dissolution of siliceous microfossils in other siliceous-rich areas.

Other studies of Leg 115 materials (Hempel and Bohrmann, this volume) have indeed documented the presence of clinoptilolite, a diagenetic silicate mineral, forming mainly in the sediments devoid of siliceous microfossils. It is unclear, however, why this mineral should form in these areas and not in sediments rich in siliceous microfossils. One possible explanation is that as clinoptilolite is a K-rich silicate; its formation needs the addition of $\mathrm{Al}(\mathrm{OH})^{-}$and $\mathrm{K}^{+}$. Such species would be present in higher concentrations in sediments that contain a greater concentration of insoluble minerals. In fact, the interval between 10 and $20 \mathrm{Ma}$ corresponds to a period of relatively low carbonate accumulation and high concentrations of acid-insoluble minerals (Peterson and Backman, this volume).

We propose, therefore, that the low Si concentrations of present-day power waters in sediments between 10 and $20 \mathrm{Ma}$ are primarily a consequence of the formation of clinoptilolite in this interval. The formation of this mineral would not be possible without the presence of $\mathrm{K}^{+}$and $\mathrm{Al}(\mathrm{OH})^{-}$, and thus, the lower $\mathrm{Si}$ concentrations are a response to the presence of these elements. However, if abundant siliceous microfossils were originally present in these sediments, their dissolution would have provided a local source for $\mathrm{Si}$ and there would have been no present-day Si minimum unless all the available microfossils had already been dissolved. Although it is also possible that most of the siliceous fossils dissolved before burial during this time in- 
terval as a consequence of the lower rates of sedimentation, the disappearance of siliceous fossils, the shoaling of the CCD, a pronounced carbon isotopic shift at Site 709 , and numerous other geochemical changes (Baker et al., this volume) are surely more than coincidence.

\section{CONCLUSIONS}

The total amounts of carbonate recrystallization based on the $\mathrm{Sr}^{2+}$ flux from the sediments range from $<0.2 \%$ at Site 705 to $>50 \%$ at Site 709 . Of the so-called "carbonate" sites, the total amount of recrystallization was the highest at Site 709, and decreased with increasing water depths at Sites 708 and 711 . Low rates of recrystallization were also observed at Site 707, the shallowest site. At all sites the highest rates of recrystallization occurred in the upper 50 mbsf in sediments of less than $5 \mathrm{Ma}$.

The rate of carbonate recrystallization calculated at Site 716 using the $\mathrm{Sr}^{2+}$ flux method was similar to rates at Sites 709 and 710 . This result was similar to that obtained from previous sites drilled in metastable carbonate assemblages containing high amounts of aragonite and HMC.

In the deeper water sites (Sites 708, 709, 701, and 711), concentrations of sulfate in the interstitial pore fluids decreased in excess of what might be expected from the rise in alkalinity, suggesting loss of $\mathrm{Ca}^{2+}$ and alkalinity during the precipitation of calcium carbonate. Such precipitation could have occurred either in the sediments or during retrieval of the core. Evidence for this latter hypothesis is provided by a comparison of chemical analyses on fluids obtained using the Barnes in-situ water sampler and waters squeezed from the sediments. Recalculation of the apparent $\mathrm{Ca}^{2+}$ concentration gives, in some instances, a profile with a concave upward slope, suggesting convection of fluid through the sediments (Sites 708, 709, 710, and 711).

Although the gradients of $\mathrm{Ca}^{2+}$ and $\mathrm{Mg}^{2+}$ in the Leg 115 sites would normally be considered to be conservative, they are influenced by recrystallization and loss of $\mathrm{Ca}^{2+}$ during core retrieval. These processes produce differences in correlation between these two elements. For these reasons, measured $\mathrm{Ca} / \mathrm{Mg}$ gradients are not truly reflective of those actually produced as a result of basement alteration and subsequent diffusion, and therefore cannot be used to indicate either the felsic or mafic nature of basement rocks.

\section{ACKNOWLEDGMENTS}

We would like to thank members of Leg 115 scientific party, technicians, and crew. In particular, thanks are due to Kate Sigler-Tauxe and Tamara Frank for help in the chemistry laboratory and Bettina Domeyer for help with the X-ray diffractometer when it worked. Naja Mikkelsen is thanked for stimulating interest in the Si data and access to her abundance information on siliceous microfossils. Help with the shore-based analyses was provided by Janet McDaneld. This is a contribution from the Stable Isotope Laboratory in the Division of Marine Geology and Geophysics at the Rosenstiel School of Marine and Atmospheric Science, University of Miami.

\section{REFERENCES}

Backman, J., Duncan, R. A., et al, 1988. Proc. ODP, Init. Repts., 115: College Station, TX (Ocean Drilling Program).

Baker, P. A. 1986. Pore-water chemistry of carbonate-rich sediments, Lord Howe Rise, southwest Pacific Ocean. In Kennett, J. P., von der Borch, C. C., et al., Init. Repts. DSDP, 90: Washington (U.S. Govt. Printing Office), 1249-1256.

Baker, P. A., and Bloomer, S. H., 1988. The origin of celestite in deepsea carbonate sediments. Geochim. Cosmochim. Acta, 52:335-340.
Baker, P. A., Gieskes J. M., and Elderfield, H., 1982. Diagenesis of carbonates in deep-sea sediments-evidence from $\mathrm{Sr}^{2+} / \mathrm{Ca}^{2+}$ ratios and interstitial dissolved $\mathrm{Sr}^{2+}$ data. J. Sediment. Petrol., 52:71-82.

Dyrssen, D., and Sillen, L. G., 1967. Alkalinity and total carbonate in sea water: a plea for p-T independent data. Tellus, 19:119-121.

Emerson, S., Grundmanis, V., and Graham, D. 1982. Carbonate chemistry and marine pore waters: MANOP sites C and S. Earth Planet. Sci. Lett., 61:220-232.

Elderfield, H., Gieskes, J. M., Baker, P. A., Oldfield, R. K., Hawkesworth, C. J., and Miller, R., $1982 .{ }^{87} \mathrm{Sr} /{ }^{86} \mathrm{Sr}$ and ${ }^{18} \mathrm{O} /{ }^{16} \mathrm{O}$ ratios, interstitial water chemistry and diagenesis in deep-sea carbonate sediments of the Ontong-Java Plateau. Geochim. Cosmochim. Acta, 46: 2259-2268.

Gieskes, J. M., 1973. Interstitial water studies, Leg 15-alkalinity, pH, $\mathrm{Mg}, \mathrm{Ca}, \mathrm{Si}, \mathrm{PO}_{4}$ and $\mathrm{NH}_{4}$. In Heezen, B. C., MacGregor, I. D., et al., Init. Repts. DSDP, 20: Washington (U.S. Govt. Printing Office), 813-829.

1974. Interstitial water studies, Leg 25. In Simpson, E.S.W., Schlich, R., et al., Init. Repts. DSDP, 25: Washington (U.S. Govt. Printing Office), 361-394.

1981. Deep Sea Drilling interstitial water studies: implications for chemical alteration of the oceanic crust, Layers I and II. In Warme, J. E., Douglas, R. G., and Winterer, E. L. (Eds.), The Deep Sea Drilling Project: A Decade of Progress. Spec. Publ., Soc. Econ. Paleontol. Mineral. 32:149-167.

Gieskes, J. M., Elderfield, H., and Palmer, M. R., 1986. Strontium and its isotopic composition in interstitial waters of marine carbonate sediments. Earth Planet. Sci. Lett., 77:229-235.

Gieskes, J. M., and Peretsman, G., 1986. Water chemistry procedures aboard JOIDES Resolution-some comments. ODP Tech. Note, 5: $1-46$.

Grasshoff, K., 1976. Methods of Seawater Analysis: New York (Verlag Chemie).

Hansson, I. 1973. A new set of $\mathrm{pH}$ scales and standard buffers for sea water. Deep-Sea Res., 20:479-491.

Kastner, M., 1979. Silica polymorphs. In Burns, R. G. (Ed.), Marine Minerals: Reviews in Mineralogy. Mineral Soc. Am., 6:99-110.

Lawrence, J. R., Gieskes, J. M., and Broecker, W. S., 1975. Oxygen isotope and cation composition of DSDP pore water and the alteration of Layer II basalts. Earth Planet. Sci. Lett., 27:1-10.

Li, Y. H., and Gregory, S., 1974. Diffusion of ions in seawater and deep sea sediments. Geochim. Cosmochim. Acta, 34:703-714.

Manheim, F. T., and Sayles, F. L., 1974. Composition and origin of interstitial waters of marine sediments based on deep sea drill cores. In Goldberg, E. D. (Ed.), The Sea (Vol. 5): Marine Chemistry: New York (Wiley-Interscience), 527-568.

Matter, A., Douglas, R. G., and Perch-Nielsen, K., 1975. Fossil preservation, geochemistry and diagenesis of pelagic carbonates from the Shatsky Rise, northwest Pacific. In Larson, R. L., Moberly, R., et al., Init. Repts. DSDP, 32: Washington (U.S. Govt. Printing Office), 891-921.

McDuff, R. E., 1981. Major cation gradients in DSDP interstitial waters: the role of diffusive exchange between seawater and upper oceanic crust. Geochim. Cosmochim. Acta, 45:1705-1713.

Sandstrom, M., and Gieskes, J. M., 1974. Interstitial water studies, Leg 24. In Fisher, R. L., Bunce, E. T., et al., Init. Repts. DSDP, 24: Washington (U.S. Govt. Printing Office), 799-810.

Sayles, F. L., and Manheim, F. T., 1975. Interstitial solutions and diagenesis in deeply buried marine sediments: results from the Deep Sea Drilling Project. Geochim. Cosmochim. Acta, 39:103-127.

Schlager, W., and James, N. P., 1978. Low-magnesian calcite limestones forming at the deep-sea floor, Tongue of the Ocean, Bahamas. Sedimentology, 25:675-702.

Schlanger, S. O., and Douglas, R. G., 1974. The pelagic ooze-chalklimestone transition and its implication for marine stratigraphy. In Hsü, K. J., and Jenkyns, H. C. (Eds.), Pelagic Sediments: On Land and Under the Sea. Spec. Publ., Int. Assoc. Sediment. 1:117-148.

Stout, P. M., 1985a. Chemical diagenesis of pelagic biogenic sediments from the equatorial Pacific [Ph.D. dissert.]. Univ. of Calif., San Diego.

sediments from the eastern equatorial Pacific. In Mayer, L., Thayer, 
F., Thomas, E., et al., Init. Repts. DSDP, 85: Washington (U.S. Govt. Printing Office), 805-820.

Swart, P. K., and Guzikowski, M., 1988. Interstitial water chemistry and diagenesis of periplatform sediments from the Bahamas, Ocean Drilling Program Leg 101. In Austin, J. A., Jr., Schlager, W., Palmer, A. A., et al., Proc. ODP, Sci. Results, 101: College Station, TX (Ocean Drilling Program), 363-380.
Weiss, R. F., Broecker, W. S., Craig, H., and Spencer, D., 1983. GEOSECS Indian Ocean Expedition Hydrographic Data (Vol. 5): Washington (U.S. Govt. Printing Office).

Date of initial receipt: 1 June 1989 Date of acceptance: 12 January 1990 Ms 115B-187 